\title{
CONCEITO OBJETIVO, DENOMINAÇÃO EXTRINSSECA E ENTIA RATIONIS EM FRANCISCO SUÁREZ (1548 - 1617)
}

André Rangel Rios'

SiNTESE - Suárez, talvez o principal expoente da Escolástica do século XVI, em suas Disputationes metaphysicae, trabalha, entre outros temas, o do conceito objetivo. Atendo-se principalmente à disputaçăo 2 , secção $\mathrm{n}^{2} 1$, procura-se mostrar a fecundidade de tal noçã̃o, desenvolvendo, para tanto, os temas: o conceito formal enquanto ato mental e enquanto imago, a doutrina da denominação extrínseca: a denominaçāo extrinseca e os entia rationis, a denominação extrinseca e os possiveis.
ABSTRACT - Suárez, perhaps the most important representative of the scholastic philosophy in the sixteenth century, studies his Distisputationes metaphysicae, among other subjects, the objective concept. Viewing mainly the Second disputatio, section 1, the author shows the richness of such a notion. Consequently he develops the following aspects: the formal concept as a mental act and as imago; the doctrine of the extrinsical denomination, the extrinsical denomination and the entia rationis. The extrinsical denomination and the possibilia.

\section{$\S 1$ - $\mathrm{O}$ conceito formal enquanto ato mental e enquanto imago (DM 2,1,1) 0} conceito formal enquanto imago é a significatio/ Conceito formal, conceito objetivo e som vocal/ o intermediário interdito: a denominação extrínseca'

Instituto de Medicina Social (IMS) - Universidade Estadual do Rio de Janeiro (UERJ).

Cf. traduçāo completa de DM 2,1,1 no fim do texto. (DM 2,1,1 leia-se: Suárez Disputationes Metaphysicae in Opera omnia vols. 25 e 26; disputação 2, seção 1, número 1.] Cabe aqui um esclarecimento prévio. Suárez fala em denominatio extrinseca. Segundo o seu sentido próprio em Suárez a palavra denominatio deveria ser traduzida por "denotação" e não por "denominação". O que está em questão é o referir ou o denotar e não o "indicar algo pelo nome" ou o "dar um nome a alguma coisa". O "dar nome a alguma coisa" ou o "indicar algo pelo nome" pressupōem um denotar mental que ocorreria sem recurso à linguagem oral ou escrita. $\mathrm{O}$ ato de dar nome às coisas (e consequientemente a linguagem oral e escrita em geral) é um ato reflexivo que apoia-se sobre esta denotaçăo, por assim dizer, pré-lingüistica. $\mathrm{O}$ ato de dar nome, enquanto um ato reflexivo, é um ens rationis. A denominaçăo extrínseca, ou melhor, a denotação extrinseca - como veremos - não é um ente de razão. Quero porém deixar claro que, por uma certa comodidade, não me preocupei em traduzir sempre denominatio por "denotação"; muitas vezes usei "denominaçâo". Também usei promiscuamente ora o verbo correspondente "denotar" ora o verbo "denominar". Fique o leitor, assim, avisado de que o que está em questão é o ato nảo reflexivo de "denotar coisas" e não o ato reflexivo de "dar nomes às coisas".

\begin{tabular}{|l|l|l|l|l|l|}
\hline VERITAS & Porto Alegre & v. 42 & $\mathrm{n}^{2} 3$ & Setembro 1997 & p. $719-750$ \\
\hline
\end{tabular}


O conceito de conceptus objectivus é um dos conceitos fundamentais do pensamento de Suárez. O conceptus objectivus entis é nada menos do que o objeto da metafisica. A doutrina do conceito objetivo/conceito formal é discutida principalmente na disputatio 2 sobre o conceito de ser. ${ }^{2}$

DM 2,1,1 é uma das passagens mais citadas de Suárez. É exatamente para explicar o que Suárez entende por conceito objetivo e por conceito formal que se recorre a ela. Daqui resultam também interpretações sempre algo insuficientes do pensamento de Suárez. Primeiro porque basear-se em apenas uma passagem para interpretar o pensamento de um filósofo é, obviamente, um procedimento em geral condenável e, além disso, porque esta passagem, tal como todas em filosofia que dizem respeito a questões fundamentais, não é livre de problemas. Há que se ressaltar, de início, que neste trecho Suárez se expressa de uma maneira algo rude. Ele destitui o conceito formal de todo valor semântico. Com base apenas no que Suárez diz neste trecho teriamos de admitir que o conceito formal não é nada além de um ato do intelecto, isto é, seria algo de individual, algo existindo individualmente na alma de cada indivíduo. Suárez diz:

... conceptus formalis dicitur actus ipse...

... formalis [sc. Conceptus] semper est vera ac positiva res et in creaturis qualitas menti inhaerens...

... conceptus formalis semper est res singularis et individua, quia est res producta per intellectum, eique inhaerens..."

Comentando esta passagem Revius criticará Suárez ao indicar que, segundo o próprio Suárez no título desta sectio (conceptus formalis omnibus entibus communis)," o conceptus formalis entis teria de estar em relação com todas as coisas. Porém o que Suárez está dizendo é que o conceito formal é um acidente na alma, a saber, uma qualidade da terceira espécie da qualidade (passio et passiva qualitas). Revius comenta:

Individuum [sc, o conceito formal é um indivíduo] sí in se ut qualitas consideratur, at, ut est omnibus communis, minime, nullum enim individuum est omnibus commune.

neque enim hic considerandus est conceptus mentis ut in se est, sed ut repraesentat sive, ut alii loquuntur, non ut est in ratione rei, sed in ratione imaginis. (v. G. Camerar. Select. Disp. p. 3 q. 2) in se est qualitas et quidem tertiae speciei. quid hoc ad rem de qua agitur? quaeritur enim de conceptu omnibus entibus communi. si conceptus omnibus communis in sua natura, id est, ut qualitas consideratur, jam omne ens erit qualitas."

Há em DM 2,1,1 uma redução do conceito formal enquanto representação intencional ao ato mental enquanto algo de individual, isto é, enquanto algo de "fisico". Tal redução não explica, ou melhor, torna enigmática qualquer explicação de como um conceito formal pode estar em relação com diversas coisas ao mesmo tempo. Dizer que o conceptus objectivus entis é um ato mental individual não esclarece o que há que se compreender quando se fala em um conceito formal de

Cf. Honnefelder [2] p. 214-246.

DM 2,1,1.

O titulo completo desta sectio 1 da disputaçâo 2 é: Utrum ens in quantum ens habeat in mente nostra unum conceptum formalem omnibus entibus communem.

6 Jacobus Revius p. 24. 
ente (ens). Afinal, o que tem que ser esclarecido é o estar em relação do ato mental com a coisa que ele denota, não o caráter físico e individual de tal fato. Em outras palavras: Suárez tem que esclarecer como os sons vocais vêm, através dos conceitos formais, a ser algo denotante. $O$ que os sons vocais expressam (digamos: o que neles assume a função semântica do sentido fregeano) ${ }^{a}$ são para Suárez os conceitos formais (...voces exprimunt conceptus formales mentis...). Suárez retornará mais tarde, ainda nesta sectio 1, a esta questão e enfraquecerá estas duras afirmações iniciais. Ele não mais tratará o conceito formal apenas in ratione rei, mas in ratione imaginis, tal como, aliás, Revius exige na passagem que citei de seu comentário das DM. Suárez diz então:

...sumit enim mens illa omnia solum ut sic, format unam imaginem unica repraesentatione formali repraesentantem id quod est, quae imago est ipse conceptus formalis..."

...hic conceptus [sc. Formalis] est per modum cujusdam simplicis imaginis naturaliter repraesentantis id, quod per vocem ad placitum significatur...' (Grifado por mim)

O sentido de uma palavra é, portanto, o conceito formal. O conceito formal é aquilo através do que uma voz, um som vocal, se torna algo denotante, ou seja, aquilo, através do que é atribuído por convenção um sentido a um som vocal. ${ }^{10}$ Numa comunidade lingüística uma palavra é usada de um modo unitário porque ela foi fixada num conceito formal enquanto este é uma imago unitária (imago unica). Se Suárez fala em 2,1,1 do conceito formal como sendo uma pluralidade de qualidades em diversos intelectos, ele se refere na passagem que acabei de citar, ao contrário, ao caráter unitário do conceito formal enquanto imago. Como, porém, estas qualidades, dispersas em vários intelectos, podem ser algo de unitário, não nos esclarece Suárez, e não nos esclarece não só aqui, mas também em nenhuma outra de suas obras. Nesta seção 1 ele se ocupa apenas da questão da unidade do conceptus formalis entis; aqui ele pressupõe tacitamente que também os outros conceitos formais têm tal caráter unitário.

0 conceito formal enquanto imago é, assim, algo unitário (unam imaginem unicam), que é anterior às palavras (hic conceptus prior est voce), logo ele, de certo modo ao menos, independe das palavras e pode denotar, se for o caso, várias coisas, ou seja, o conceito formal é também algo unitário e que pode, por vezes, estar referindo várias coisas, isto é, que pode ser comum a várias coisas. Tal é o caso do conceptus formalis entis, que é o fundamento da impositio da palavra "ens". Vejamos agora as seguintes passagens de Suárez:

(1) ...vox, ens, non solum materialiter est una, sed etiam unam habet significationem ex primaeva impositione sua..."

- Esta comparação de Suárez com Frege foi empreendida de um modo breve e limitado por Hickman. Indiquei em Rios [1] passim as inúmeras dificuldades de tal comparação.

DM 2,2,23.

DM $2,1,11$.

DM $2,1,13$.

* DM 2,1,13: ...quia, ut dixi, hic conceptus prior est voce, et impositione ejus ad res tali modo significandas. Nam licet quoad nos conceptus saepe formentur mediis vocibus, qui ex se parit vocem qua exprimitur, et est origo impositionis...

11 DM 2,1,9. 
(2) ...huic voci [sc. Ens] respondere etiam in mente unum conceptum formalem, quo immediate et adaequate concipitur quod per hanc vocem significatur. ${ }^{D}$

(3) ...nomen ens, ex propria et primaeva impasitione, habet significationem communem omnibus entibus, ut patet, tum ex communi usu, et apprehensione talis vocis, tum ex formali vel quasi formali significato ejus, quod est esse, quod de se commune est, et intrinsecum omnibus realibus entibus; tum denique quia illa impositio orta est ex unico conceptu formall entis ut sic." (Grifado por mim)

Ao som vocal (vox) "ens" é atribuída uma determinada significatio com base num único (isto é, unitário) conceito formal (ex unico conceptu formali entis). O som vocal "ens" tem, assim, uma significatio (unam habet significationem) correspondendo a ele também um conceito formal. O conceito formal enquanto imago é a significaçăo unitária que é atribuída a um som vocal. Retomemos aqui a comparação entre Suárez e Frege contrapondo a significatio unitária com o Sinn de Frege. Ambos são anteriores ao som vocal e inalteráveis. Contudo, enquanto Frege claramente separa o sentido (o $\operatorname{Sinn}$ ) do ato mental, Suárez não distingue o conceito formal enquanto significatio do ato mental enquanto algo físico tão incisivamente. O conceito formal é a significatio e a significatio (do som vocal "ens") e, assim, é comum a todas as coisas, ou seja, denota, do mesmo modo, todas as coisas. Esta significatio é um denotar, um referir. A significatio de um som vocal é o conceito formal enquanto denotante o que a ela corresponde. Para Suárez um som vocal refere-se a uma pluralidade de coisas de um modo unitário apenas se há um ato mental que assume a função de denotante. Suárez não reconhece explicitamente que haja algo de semântico que independa do ato mental, isto é, que seja, por assim dizer, algo de transcendental.

Retornando agora para DM 2,1,1 temos de conceder que Suárez, de fato, se expressa ai de um modo por demais duro, uma vez que ele, afinal, entende o conceito formal como sendo não só algo de físico e individual, mas também como tendo funções semânticas. Contudo, uma vez que Suárez não caminha em direção a aceitar o semântico como sendo algo de transcendental, resta a ele tentar reduzir a significatio ou ao fundamento denotante (isto é: ao conceito formal enquanto um ato mental) ou às coisas denotadas (isto é: ao conceito objetivo enquanto aquilo que nas coisas corresponde ao denotar do ato mental).

Contudo Suárez diz também que há denominationes extrinsecae e connotationes" que são independentes dos atos mentais. Como veremos mais abaixo, o predicamento do habitus, p. ex., consiste em uma denominação extrínseca que independe dos atos mentais.

\section{Vejamos agora como Suárez em DM 2,1,1 esclarece o conceito objetivo:}

Conceptus objectivus dicitur res illa, vel ratio, quae proprie et immediate per conceptum formalem cognoscitur seu repraesentatur; ut, verbi gratia, cum hominem concipimus, ille actus, quem in mente efficimus ad concipiendum hominem, vocatur conceptus formalis; homo autem cognitus et repraesentatus illo actu dicitur conceptus objectivus, conceptus quidem per denominationem extrinsecam a conceptu formali, per quam objectum ejus concipi dicitur, et ideo recte dicitur objectivus, quia non est conceptus ut forma intrinsece

\footnotetext{
12 DM 2,1,9.

1) DM $2,2,24$.

n Nẫo discutirei aqui a questão da connotatio. Sobre isto cf. Rios [1] §̧క 9-11.
} 
terminans conceptionem, sed ut objectum et materia circa quam versatur formalis concep-

tio, et ad quam mentis acies directe tendit..." (O grifo é meu)

Nesta passagem o que temos é que o conceito objetivo é esciarecido com recurso ao conceito formal. O conceito objetivo consiste numa denominação extrínseca do conceito formal. Particularmente conspicuas são porém as oscilaçōes: "res illa, vel ratio" e "cognoscitur seu repraesentatur". Ou seja, nesta passagem é dito do conceito objetivo que ele, por um lado, é a coisa (res illa) ou o objeto (objectum et materia circa quam), mas que, por outro lado, ele é o conhecimento (ratio). Portanto, do conceito objetivo, ora é dito que ele é o conhecimento próprio e imediato, ora que ele é apenas a representação de algo.

Além disso, enquanto o conceito formal é dito ser sempre uma coisa positiva e individual, a saber, uma qualidade inerindo no intelecto, o conceito objetivo por vezes não é positivamente uma coisa, uma vez que nós apreendemos conceitualmente também as privaçōes e os outros entia rationis.

Há também, sempre ainda segundo esta passagem, tanto os conceitos objetivos que apresentam - e, portanto, são - uma coisa individual, quanto os que apresentam algo universal e confuso, como, p. ex., homo, substantia etc. Assim, o conceito objetivo só é existente se ele é o conceito objetivo de uma coisa existente realmente, de outro modo ele não é.

O conceito objetivo é, conseqüentemente, por vezes a coisa existente mesma, por vezes só o conceito (a saber, se a coisa não existe); por vezes uma coisa positiva, por vezes uma coisa "fingida" (ou seja: por vezes uma coisa existente, por vezes uma não existente); por vezes uma coisa individual, por vezes universal ou confusa.

Visto deste modo há que se dizer que o próprio conceito de conceito objetivo é um conceito equivoco, pois entre o ens reale e o ens rationis não é possivel a analogia e, ainda menos, a univocidade. Esta equivocidade do conceito objetivo se deve a que o conceito formal pode denotar tanto coisas reais quanto coisas só pensadas (rationis). Esta denotação surge por sua vez por meio de uma forma própria ao conceito formal que é extrínseca à coisa denotada ou que é pensada como sendo extrinseca a ela e que, portanto, tem a mesma realidade do conceito formal, de modo que o denotar do conceito formal (ao menos enquanto só se considera este denotar com base na forma denotante) nâo pode ser 0 fundamento da equivocidade do conceito de conceptus objectivus, sobretudo porque - como acabamos de ver acima - o conceito formal enquanto algo denotante é unitário. Resumindo: o conceito de conceito objetivo é equívoco, (1) porque apreende-se conceitualmente tanto entia realia quanto entia rationis e (2) porque o conceito objetivo - uma vez que sua realidade é a mesma que a da coisa apreendida - é ora algo real ora não é nada.

" DM 2,1,1.

" Uso o verbo "fingir" como verbo transitivo direto para traduzir a palavra latina "fingere". "Fingere" não é "imaginar". "Imaginar" é apenas um típo de "fingir". Isto é. Enquanto um ente imaginado é apenas um ens rationis, hả os outros entia rationis que são "fingidos" mas que nảo são imaginados tais como o matrimônio entre duas pessoas, a relação de senhor e escravo etc. 
No entanto, haveria de se conceder ainda que também o conceito de conceptus formalis é equívoco. Pois o conceito formal, ao menos nos textos de Suárez, é tanto algo de "físico" (isto é, algo da ordem do ôntico) quanto algo semântico (isto é, algo que cumpre funçōes semânticas). Enquanto algo físico ele pode ser uma pluralidade de qualidades espalhadas em diversos intelectos; enquanto algo semântico ele é o sentido unitário de uma palavra. Este é evidentemente também o caso do próprio conceito formal de conceito formal.

Retornemos ao texto da Disputação 2. O que podemos por ora concluir é que - uma vez que Suárez não reconhece as conseqüências do distinguir o conceito formal enquanto algo físico e enquanto algo semântico - sua argumentação nesta Disputação resultará confusa. Primeiramente afirma Suárez, áspera e firmemente, que $\mathrm{o}$ conceito formal é tão-somente algo físico e que o conceito objetivo não tem como realidade senão a própria realidade da coisa denotada. Entre a realidade físico-psicológica do ato mental e a realidade (ou não-realidade) da coisa denotada não deixa Suárez nenhum espaço para que se aceite uma realidade intermediária para o semântico. Ou seja, Suárez não deixa espaço para que se aceite uma, por assim dizer, dimensão semântica autônoma ou com uma realidade específica. Pouco mais tarde porém - ainda na mesma seção 1 - Suárez reabilita a unidade da significatio e atribui tal unidade ao conceito formal. Na seção 2 ele chega mesmo a provar, e nisto ele se baseia na então já aceita unidade semântica do conceito formal, que ao conceito formal de ente (enquanto algo denotante e não meramente físico) corresponde junto às coisas um conceito objetivo de ente. Este conceito objetivo de ente - ao contrário do que, em vista de DM 2,1,1, se poderia esperar é também unitário.

Para Suárez há, a principio, somente individuos. Entre os individuos inclui-se também os conceitos formais enquanto qualidade que inerem em diversos intelectos individuais. Este individualismo não pode porém propor uma semântica minimamente satisfatória. É somente quando Suárez - sem o haver nunca fundamentado de um modo explícito - admite em sua metafísica significações unitárias e as atribuir aos conceitos formais, que por meio deste contrabando, senão de uma semântica, ao menos de elementos indispensáveis para a formulação de uma semântica, que se torna possível que Suárez fale do apreender do intelecto e do comunicar este apreender a outros intelectos individuais, a saber, que ele fale do apreender as coisas individuais (isto é, os seus conceitos objetivos), os universais (isto é, os conceitos objetivos que junto às coisas correspondem a um conceptus formalis communis) e o próprio ser (ens) enquanto objeto da metafisica (isto é, o conceptus objectivus entis).

É somente por meio de uma aceitação tácita de uma dimensão semântica que se torna possível a Suárez compreender o objeto da metafisica como sendo o conceptus objectivus entis. Com sua peremptória afirmação de que o conceito formal é uma qualidade inerente a cada intelecto Suárez não parece ter podido ir muito longe. A rigor ele deveria era ter se ocupado do processo físico de constituição desta qualidade, ou seja, ele deveria haver discutido o papel do intelecto agente e do intelecto possivel para esclarecer como de processos físico-psicológicos pode resultar algo que seja físico e que seja, ao mesmo tempo, algo semanticamente 
unitário. Contudo, uma tal discussão só poderia ter como resultado que o ato mental é algo físico, porém nunca teria como resultado o esclarecimento de como de algo físico surge algo com um caráter semântico. No entanto, ainda que tal discussão resultasse em successo ela trania consigo um outro inconveniente: estarse-ia buscando na física o fundamento da metafísica, quando a metafísica enquanto ciência primeira não deveria fundar-se na fisica ou dela ser deduzida. Em todo o caso, como vimos, Suárez não reduz na Disputação 2 a semântica à física; ele fala em DM 2,1,1 como se isto fosse possivel, mas depois recorre ao semântico sem buscar reduzi-lo ao fisico. O que, ao contrário, Suárez de certa maneira faz é fundar a metafísica na dimensão semântica. Mas isto também não ocorre de um modo explicitado. Ou seja, as seções 1 e 2 da Disputação 2 acabam por resultar numa peculiar mistura de análise semântica e especulação metafísica. Suárez deixa entremeada ou, antes, emaranhada a discussão do objeto da metafísica e a do sentido da palavra "ens". Só o que ainda se poderia dizer, embora com certo risco, é que a nesta Disputação 2 em primeira linha a discussão focaliza a questão do sentido do ser e só então vai-se à questão do ser enquanto ser. É, pode-se dizer, para contemporizar esta preponderância dada à questão do sentido da palavra "ens" que Suárez diz:

Haec enim tria, conceptus formalis, objectivus, et vox, proportionem inter se servant, et ideo ab uno ad aliud saepe argumentamur, non quidem vitiosum circulum commitendo, sed de unoquoque sumendo quod nobis notius, aut ab aliis facilius concessum videtur."

Propriamente falando o mais originánio é o conceito formal enquanto imago (ou seja, enquanto significatio). É, afinal, através da imago/significatio que a coisa é conhecida e denotada: ela é o fundamento do dar sentido (impositio) a um som vocal. Conhecer consiste, em última instância, em adquirir conceitos formais. É através de conceitos formais que se vem a apreender as coisas e a compreender as palavras. Baseado em que Suárez vem afirmar que se pode compreender melhor o conceito formal de ser quando se dá atenção ao uso comum da palavra (ex usu communi)? Afirmar isto não é conceder que o sentido de uma palavra pode ser um outro diferente daquele que se pôs em relação com o meu conceito formal individual que inere na minha alma? Com base nesta passagem se pode concluir que, para Suárez, o sentido de um conceito formal ou de uma palavra não pode ser atribuido, nem aos conceitos formais individuais, nem só ao uso da palavra e nem àquilo que é denotado, mas a algo que conserva juntos estes três. $\mathrm{O}$ que, frente a estes três, pode ser considerado como autônomo e que os conserva interrelacionados é o conceito formal enquanto imago/significatio. Ou seja, visto assim, tem-se que a metafisica de Suárez baseia-se fortemente nos resultados de sua discussão do sentido da palavra "ens", sendo que ao discutir o sentido da palavra "ens" Suárez pressupõe elementos próprios a uma semântica sem nunca vir a fundamentar a admissảo deles.

Suárez propõe no seu De anima: "non enim medium datur inter ens fictum et reale"." Tal tese, pode-se dizer, programática é repetida por ele, de um modo

DM 2,2,24.

Suárez De anima lib. 4 n. 26. 
menos sucinto em outras passagens de suas obras." Suárèz proíbe aqui ou, ao menos, se proibe aqui de aceitar uma realidade intermediária entre os entes reais e os conceituais ou ficticios. Esta interdição vai de par com sua aceitação da existência somente de indivíduos. A sua doutrina dos entia rationis parece ter sido elaborada tendo como uma das finalidades dar conta de todas as entidades que tradicionalmente vinham como que reivindicando um estatuto ontológico especial. Porém já no início de sua metafísica, quando ele ainda está por esclarecer a sua compreensão do objeto da metafísica, surgem como que assombrações. Primeiro ele afirma duramente que o conceito formal é algo físico e que o conceito objetivo é a coisa apreendida. Mas entre o ato mental e o objeto se interpõe a denominação extrinseca deste ato mental. Qual o estatuto ontológico da denominação extrínseca? Depois ele atribui ao próprio conceito formal um caráter semântico unitário sem nunca pôr em discussão as contradiçōes que surgem ao longo das seções 1 e 2 com suas afirmaçōes iniciais em DM 2,1,1. O que estive aqui indicando é que este intermediário interdito é que possibilita a própria discussão da Disputação 2. Este intermediário interdito é, primeiramente, a denominação extrinseca, depois porém Suárez passa a falar também no conceito formal como imago e como significatio. É a denominação extríseca e suas concomitantes dificuldades que, a seguir, têm que ser melhor discutidas.

$\S 2$ - A doutrina da denominação extrínseca/ A denominação extrínseca enquanto denotar e enquanto ser-denotado/ A redução repetidamente tentada da denominação extrinseca (enquanto denotar) ao seu fundamento e da denominação extrínseca (enquanto ser-denotado) à coisa denotada/ A redução ontológica do predicamento do hábito à realidade de seus correlatos constitutivos/ DM 54,2,1014/ De anima lib. 6 c.3 n.24

Há que se começar indicando que, em Suárez, "denominatio extrinseca" pode significar tanto o denotar quanto o ser-denotado. Suárez, porém, nunca explicitou esta duplicidade da expressão "denominação extrínseca" e parece, ele próprio nem sempre ter tido consciência de tal duplicidade. É necessário, contudo, que prestemos atenção a esta duplicidade para que possamos compreender devidamente certas argumentações de Suárez.

Esta duplicidade da expressão "denominação extriseca" pode ser evidenciada sem dificuldade na doutrina Suáreziana dos universais. Para Suárez o universal surge de uma abstração direta do intelecto possível e não por meio de atos mentais comparativos. O resultado do processo de abstração é um conceito formal. Este conceito formal seria, porém, - segundo DM 2,1,1 - algo físico-individual e não universal. Universal seria o seu denotar, isto é, o seu conteúdo denotante enquanto denota várias coisas. O universal seria, deste modo, uma denominatio extrinseca ab actu rationis." Este universal é o que recebe o nome de universale metaphysicum; a principio, ele não é um ens rationis. Com base nesta denominação extrínseca é que o intelecto pode "fingir", isto é, constituir ficcionalmente (ou

* Ct. DM 54,2,12; ...vel admittènda enunt alia genera entium, quae nec realia sint nec rationis.

D DM 6,7,2. 
seja, reflexivamente) entia rationis. O intelecto pode, portanto, "fingir" o universal, tanto como algo que persistiria separadamente e que não seria então capaz de distribuir entre várias coisas o ser delas, quanto como algo que como um acidente ineriria nas coisas." Trata-se assim, no primeiro caso, de uma hipóstase ficcional (isto é, resultante de um ato mental reflexivo) do próprio denotar do ato mental e, no segundo caso, de uma hipóstase ficcional do ser-denotado da coisa (como se este ser-denotado fosse algo que aderisse a esta coisa). Tais hipóstases ficcionais evidenciam, portanto, que a compreensão da denominação extrínseca em Suárez, ora a aproxima do ato mental denotante, ora a aproxima do objeto denotado.

Mas o que é uma denominação extrínseca? Suárez não nos propõe dela nenhuma definição. Doyle apresentou e comentou grande quantidade de textos relativos à denominação extrínseca vindo, ao final, a concluir que Suárez não chegou elaborar uma doutrina da denominação extrínseca completa e de fato consistente. ${ }^{p}$ Penso que esta incompletude não é casual, isto é, que ela não é algo que poderia ter sido contornada com mais atenção e trabalho, antes penso que esta incompletude na doutrina e esta duplicidade na expressāo "denominação extrinseca" é exatamente uma falha na sistematicidade das DM, falha que possibilita a sistematicidade das DM. Retornaremos no final deste artigo a esta questâo.

Denominatio extrinseca é uma expressão relativamente comum na Escolástica. Ela se encontra também, p. ex., em Tomás de Aquino quando ele discute os seis últimos predicamentos. Para vánios escolásticos, entre os quais se inclui também Vasquez, toda a denominação extrinseca está em dependência de um ato mental. Suárez, ao contrário, entende que além dessas há denominações extrínseca que são anteriores à atividade do intelecto. ${ }^{n}$ Suárez indica ainda que não entende com "denominação extrínseca" propriamente o denominar enquanto dar um nome a alguma coisa (neste sentido o denominar é de fato sempre o resultado de um ato do intelecto), mas antes as correlações e habitudines" nas quais o dar nome às coisas necessariamente se apoia.

Uma vez que Suárez não nos oferece ou não pode nos oferecer nem uma definição nem um tratamento sistemático do tema denominação extrínseca buscarei,

n DM 6,7,3: ...concipitur enim natura communis ut apta ad existendum in multis, et sic concipi potest ut habens relationem aptitudinis ad communicandum llis suum esse; potest item concipi ut actu existens in illis, et ut sic habens relationem actualem, seu rei actu se communicantis multis. Sicut enim in accidente intelligimus relationem aptudinalis, vel actualis, vel actualis inhaesionis, ita eam possumus fingere vel excogitare in natura universali ut communicabili, vel ut communicata multis.

Doyle p. 157: “...it shoud be evident that extrinsic denomination is in Suarez's thought an ambiguous item. At times, it seems close to, if not synonimous with, a mere naming from outside. But at other, more frequent, and more important times, it is definitely regarded as a feature of things thenselves". Parece-me que Doyle está aqui de certo modo se referindo ả duplicidade da expressâo "denominação extrinseca" que indiquei de início. DM $54,2,10$.

Habitudo é uma expressão geral para qualquer tipo de relação. Habitudo pode então, de acordo com o contexto, ter como tradução diferentes palavras, onde de certo modo estas traduções serão também uma especificação e determinação de seu sentido: relação (isto é, tanto para a relação predicamental quanto para a relação transcendental quanto para a relação conceitual), denominação extrinseca, denominaçăo intrinseca, conotaçăo; também se pode recorrer para a tradução a palavras terminologicamente 
apoiando-me no artigo de Doyle, apresentar extensivamente os elementos ao longo da obra de Suárez que deveriam poder ser compatibilizados numa doutrina da denominação extrínseca. Os principais elementos teóricos relativos a uma doutrina da denominação extrinseca em Suárez são:

(1) Uma denotação recebe o nome de extrínseca porque ela não acrescenta nada à coisa, isto é, a coisa nem se altera nem é causada por ela. (Nenhuma coisa é causada ou alterada por meio de uma denominação extrinseca. $)^{\text {m. }}$

(2) A denominação extrinseca não pressupõe que a coisa denotada tenha que ser real. ${ }^{*}$

(3) A forma em uma coisa que denota uma outra coisa extrinsecamente tem de ser, nesta primeira coisa, intrínseca. Assim, com o ato de ver, uma coisa é denominada extrinsecamente, a saber, é denominada enquanto o que é visto; além disso, uma coisa (o olho) é denominada intrinsecamente enquanto está vendo."

(4) Propriamente falando é a forma denominante ou denotante que se põe em relação com a coisa denominada e não a coisa denominada com a coisa denominante. ${ }^{\text {s }}$ Não somente há denominações extínsecas que independem dos atos mentais, mas há também denominações extrínsecas que dependem de atos mentais que são apenas possiveis. Suárez chama estas denominaçôes de denominationes aptitudinales, entre estas pode-se citar com particular destaque a numeralitas." As denominationes aptudinales não carecem evidentemente de uma forma denominante existindo em ato.

(5) De um ponto de vista formal uma denominação extrínseca inclui os seguintes elementos: (a) a forma denominante ou denotante (forma denominans), (b) a coisa denominada ou denotada (res denominata), (c) o pôr-em-relação (unio) da forma denotante com a coisa denotada e (d) o denotar e o ser-denotado que surgem da união, isto é, do pôr-em-relaçâo do denotante com o denotado. P. ex.: (a) a visão enquanto potência para ver, (b) a parede vista, (c) o direcionamento do olhar para a coisa e (d) o ser-visto; (a) a vestimenta, (b) o homem, (c) a distância adequada da vestimenta e (d) o estar-vestido (vestitus). ${ }^{\text {x }}$ Temos aqui, portanto, que

s DM 54,2,9: ...talis denominatio nihil ponit in re denominata; ideo enim extrinseca appellatur... DM 31,2,7: ...quae denominatio in re denominata nihil ponit... DM 32,2,14: ...sola extrinseca denominatio nihil rei ponit in re denominata. Cf. Doyle p. 145-153 nn. 2, 3, 4, 5, 7, 30, 32 e 33.

DM 31,2,7: ...neque etiam supponit, per se loquendo, aliquod reale esse... Ct. Doyle p. 146 n. 11.

" Suárez De bonitate disp. $1 \mathrm{sec} .2$ n. 21 (vol. 4 p. 285): ...forma extrinsece denominans debet prius in aliquo intrinsece reperiri: ...non est tamen necesse ut eamdem denominationem, quam extrinsece akicui tribuit, prius det intrinsece alteri, sed potest dare aliam. Exemplum clarum est in visione quae denominat objectum visum extrinsece: est tamen in potentia, quam non denominat visam, sed videntem: et in actione transeunte constat esse inhaerenter in passo, cui non dat denominationem agentis... Cf. Doyle p. 148 n. 17.

* DM 47,12,8: ... quia quod extrinsece denominat, potius refertur ad ipsum quod denominat, quam referat ipsum; atque ita actio potius refertur ad agens, quam ipsum referat, quamvis sit occasio vel conditio ut in agente resultet relatio. Cf. Doyle p. 149 n. 19.

* DM 41,1,19: Confert tamen illa habitudo [sc. a denominaçẳo extrinseca da numerabilidadel seu denominatio aptudinalis, etiamsi connotet ordinem ad facultatem animae, ut numerus, etiam ut numerus, dicatur esse in rebus, quando actu non numeratur seu cogitatur.

× DM 54,2,14: ...omnia illa revera ita sunt in re, sicut cognoscuntur, scilicet [b] res denominata, [a] forma denominans, et $[\mathrm{c}]$ illa qualiscunque unio complens denominationem, quae $[\mathrm{d}]$ potius est re- 
(c) è a denominação extrínseca enquanto denotar e (d) enquanto ser-denotado. Considerando-se ontologicamente, para Suárez, a denominação extrinseca consta só de dois elementos, a saber, da forma denominante e da coisa denotada (que pode ser um ens rationis). Ou seja, Suárez, para coibir qualquer status ontológico intermediário, tende a reduzir (c) a (a) e (d) a (b).

(6) Há denominações extrínsecas que antecedem os nossos atos mentais." Isto mostra claramente que, em Suárez, as denominaçōes extrínsecas não podem ser confundidas com os entia rationis, pois estes dependem totalmente do intelecto. Assim, uma vez que Suárez não aceita nenhuma realidade intermediária entre os entes reais e os entes conceituais, ele é levado a ter de tentar pôr estas denominações extrínsecas que independem do intelecto no plano das coisas reais. ${ }^{x}$

(7) Por vezes, uma coisa pode ser, sob um certo ponto de vista, denominada intrinsecamente $\mathrm{e}$, sob um outro ponto de vista, ser denominada extrinsecamente. Este é o caso, p. ex., dos predicamentos da actio e da passio. A passio é, segundo Suárez, um modus intrinsecus na coisa que sofreu uma alteração e a denomina intrinsecamente como uma coisa alterada, sendo que este modus não altera a coisa causadora da alteração, de modo que a coisa causadora permanecendo inalterada é apenas extrinsecamente denominada causadora. ${ }^{\text {" }}$

(8) Uma denominação extrínseca pode ser anterior a uma outra. Pode mesmo haver uma certa ordem entre várias denominações extrínsecas. A denominação extrínseca da verdade transcendental é anterior à do bem. Neste caso inclui-se também o do surgimento dos números cardinais."

(9) Os números cardinais que devido a sua serialidade tornam possivel a ciência da aritmética surgem por meio de denominações extrínsecas sucessivas das coisas contadas pelos intelecto (na realidade exterior o que há é apenas uma reuniāo de coisas ou de acidentes). ${ }^{\text {. }}$

alis habitudo. DM 53,1,3: [a] Forma igitur est vestis ipsa: [b] subjectum est homo, verbi gratia, qui induitur; $[c]$ unio hic non est alia, nisi circumpositio seu adjacentia indumenti illo modo, qui accomodatus est ad ormamentum, seu tegumentum subjecti quod vestitur; [d] concretum autem est totum hoc, homo vestitus, vel incomplexe, indutum. Também: DM 16,1,24. Ainda neste parágrafo discutirei o predicamento do hábito enquanto denominação extriseca. Cf. Doyle p. 144 n. 1.

DM 54,2,9-14. Comento mais abaixo esta passagem. Cf. Doyle p. 149 n. 1.

$\therefore$ DM 54,2,12: ...hae denominationes extrinsecae possunt fundare aliquod ens vel relationem rationis, si concipiatur tanquam aliquid in re denominata; ipsae tamen praecise sumptae non sunt proprie entia rationis. De bonitate disp. 1 sec. $2 \mathrm{n}$. 19: ...hujusmodi denominationem proprie non esse ens rationis, quod consistit in fictione intellectus sed est in rebus ipsis... Cf. Doyle p. $150 \mathrm{n} .22$.

DM 49,1,8: Dicendum ergo censeo, actionem et passionem in re non esse modos ex natura rei distinctos, sed eamdem dependentiam et emanationem formae ab agente, quatenus subjectum intrinsece afficit, vocari passionem, quatenus vero agens ipsum denominat actu agens, vocari actionem... Cf. Doyle p. 154 n. 35.

x DM 3,2,14: Denique juxta hunc modum, ad veritatem reducitur denominatio amabilis, significabilis; ad bonum reducitur ratio integri, et perfecti, et denominatio amabilis, appetibilis, et similis...Cf. Doyle p. 154 nn. 36 e 38.

\% DM 41,1,2: ...si ternarium hominum secundum se consideres, in nullo eorum est prima unitas, secunda, aut tertia; nulla enim ratio talis ordinis potest eos assignari; ille ergo ordo, si quis est, solum est rationis... DM 41,1,17: At vero constat unitates alicujus numeri secundum se non habere ordinem realem inter se, neque in eis aliquam esse ultimam vel primam; ergo oportet ut haec sumantur aliquo modo ad conceptionem nostram. DM 40,3,8: ...in propria quantitate continua men- 
(10) Denominações extrínsecas podem por vezes fundar relationes rationis inclusive as das intentiones secundae $e^{x}$ da lógica, bem como também outros entia rationis.

(11) Há relationes rationis das quais tanto o fundamento quanto o correlato se apoiam em denominações extrínsecas. P. ex.: denominar alguém como senhor, ou alguém como escravo, é para aqueles que assim são denominados extrinseco, uma vez que nada de real lhes é acrescentado. Destas denominações surge porém uma relatio rationis. Este também é o caso da relatio rationis que surge entre o homem e a mulher no casamento ou entre o vendedor e o comprador: estas relationes rationis tomam como fundamento as denominaçōes extrinsecas que surgem das vontades dos contratantes no que a vontade se refere ao que é desejado."

(12) Há também relationes rationis que não são reciprocas e que têm só uma denominação extrinseca como correlato. É o caso da relação entre uma coisa que é vista com quem a vê (isto é, com o "videns"), onde na coisa o ser-visto é uma denominação extrinseca; é o caso também da relação entre a coisa conhecida e o conhecimento, bem como o caso de Deus frente às coisas criadas; neste último caso Deus é denominado pelas coisas criadas como "criador" apenas extrinsecamente uma vez que a coisa criada nada acrescenta a Deus."

(13) Uma denominaçāo extrínseca pode servir de fundamento para uma distinctio rationis."

(14) Um ens rationis pode surgir com base numa denominação extrinseca quando a denominação extrinseca é pensada como se ela fosse algo junto à coisa, isto é, como se ela fosse algo aderido e, assim, separável da coisa. Daí se segue que, se uma pessoa pensar um conceito objetivo (ou seja, uma denominação extrínseca) como se ele fosse algo de separável da coisa denominada, então não se

suram ut mensuram semper esse per humanum accomodationem, quia nulla est major ratio quod haec res mensuret illam, quam e converso, si res ipsae secundum se spectentur. Cf. Doyle p. 155 nn. 39 e 40.

* DM 54,2,16: Atque ad hunc modum fiunt omnes similes secundae intentiones per conceptus reflexos supra priores denominationes provenientes ex conceptibus directis, quae ut diximus, non pertinent ad propriam rationem entis rationis seu ficti, de quo [sc. nesta disputação] tractamus.

DM 54,6,6: Unde ad hoc genus [sc. relationum rationis] spectant imprimis relationes omnes, quae in utroque extremo fundantur tantum in denominatione extrinseca, ut est relatio signi ad placitum, quae tam in signo, quam in signato est relatio rationis, sive tale signum sit vox, ut nomen, aut verbum, sive sit res ut sacramentum. Cum enim haec impositio ad significandum nihil rei ponat in signo nisi denominationem extrinsecam, neque etiam in signato, non potest fundare relationem realem, ut omnes docent. Deinde ejusdem sunt modi relationes domini et servi inter hominies, nam illae non fundantur nisi in quadam extrinseca denominatione sumpta a voluntate; et similes sunt aliae multae, ut omnes illae quae oriuntur ex contractibus et voluntatibus humanis, ut inter maritum et uxorem in ratione conjugum, inter ementem et vendentem ex voluntate contrahendi; et sic de aliis. Cf. Doyle p. 155-156 n.42.

* DM 54,6,7: Rursus ad aliud membrum hujus generis [sc. relationum rationis] pertinent omnes relationes non mutuae, quatenus in uno extremo rationis sunt, ut sunt relatio visi ad videntem, aut visibilis ad visum, aut scibilis ad scientiam, etc. ... Et huc etiam revocari possunt omnes relationes Dei as creaturas existentes, nam etiam illae possent dici fundari in denominatione extrinseca, quia in ipso Deo secundum se non est capacitas, atque adeo nec fundamentum ad tales relationes. Também: DM 47,15,13. Cf. Doyle p. 156 n. 43.

* DM 7,1,21: ...et sic semper est distinctio rationis, ... quia solum convenit per denominationem extrinsecam, quatenus eadem res objicitur, vel subordinatur diversis conceptibus. Cf. Doyle p. 156 n. 46. 
estaria mais falando de um conceito objetivo mas de um ens rationis constituido ficcionalmente com base neste conceito objetivo."

(15) Denominaçōes extrínsecas não podem servir de fundamento nem para relações reais nem para distinções reais. "

(16) Também um ens rationis pode servir de forma denominante de uma denominação extrínseca."

Vistos estes elementos dispersos pode-se concluir pela dificuldade de reunilos numa doutrina sistematizável. Pode-se, porém, também concluir pela importância desta doutrina. Suárez recorre à denominação extrinseca não só em sua discussão do objeto da metafísica (cf. §1), mas também, p. ex., ao discutir o tempo (onde ele se refere à numerabilidade), ao discutir os predicamentos da actio e o do habitus, bem como em sua discussão dos universais e dos entia rationis. Enfim são vários os momentos importantes de sua metafísica nos quais a discussão não caminha senão com recurso à denominação extrínseca. Vimos que este recurso à denominação extrinseca está relacionado com a recusa de Suárez em admitir uma autonomia e uma especificidade ontológica a entes que desempenhem funções semânticas. ${ }^{\circ}$ Para poder explicar, porém, as funções semânticas dos conceitos Suárez recorre à denominação extrínseca e, em sua teoria da verdade, à conotação. Conseqüentemente ele fica obrigado a esclarecer qual seja o estato ontológico da denominação extrinseca." Sua tendência básica é a de alinhar a denominação extrinseca com os entes reais, isto é, sua tendência é a de reduzir ontologicamente a denominação extrinseca à forma denominante. Tal procedimento não ocorre porém sem uma certa vacilação. A rigor ele não é satisfatório inclusive porque, como podemos ver no item (16) acima, também um ens rationis pode estar no papel de forma denominante, o que implicaria a redução da denominação extrínseca a um ens rationis, o que é inaceitável visto que, como Suárez afirma - cf. (6) acima -, as denominações extrínsecas não são entia rationis (...praecise sumptae [sc. as denominações extrínsecas] non sunt proprie entia rationis ${ }^{(1)}$. Contudo, não se deve pensar também que o recurso à denominação extrinseca se impôs a Suárez só para suprir sua recusa de entidades semânticas; na sua discussão do predicamento do hábito Suárez está nem tanto preocupado com uma questão semântica, antes é o lugar deste predicamento em sua ontologia que o está ocupando.

O que torna a discussão da denominação extrínseca particularmente relevante è o fato de que ela encontra-se dispersa e infiltrada em momentos chaves da metafisica de Suárez. Tal é também o caso da doutrina Suáreziana dos entia rationis, porém com a diferença de que para os entia rationis Suárez reservou uma

\section{Cf. DM 54,2,12.}

" DM 47,10,15: ...ratio mensurae quantitativae non est per se apta ad fundandam relationem realem, cum solum sit extrinseca denominatio rationis. Doyle p. 156-157 n. 44 e 47.

- DM 11,1,8: ...quod in se malum dicitur, a sola privatione denominari potest... Cf. Doyle p. $157 \mathrm{n}$. 49.

- $\mathrm{O}$ que năo quer dizer que a aceitaçăo de tais entidades também não viesse a levá-lo a impasses.

" Sobre a questão da conotação cf. Rios [1] §§ 9 a 12.

- DM 54,2 
disputação inteira no final das DM. Suárez reconhece que os entia rationis não são propriamente parte do objeto da metafisica, mas parece-lhe adequado tratá-lo e o faz até para melhor exclui-lo da metafísica. A rigor Suárez nem inclui nem exclui as denominações extrínsecas de sua metafisica. Elas não chegam a merecer uma đisputação só para elas, mas também não acabam por ser claramente banidas, antes há mostras da boa vontade em inclú-las o que se vê, p. ex., na própria Disputação 54 sobre os entia rationis onde as denominações extrinsecas são explicitadamente diferençadas dos entia rationis (podem elas então por isso serem ditas entes reais?) ou quando o predicamento do hábito é dito ser uma denominação extrinseca e ainda é aceito como sendo um predicamento (mas não diz também Suárez que o predicamento do hábito quase não é um predicamento?").

Para caracterizar melhor a atitude vacilante ou oscilante do texto de Suárez comentarei a seguir duas passagens das DM, a passagem da Disputaçāo 53 sobre o predicamento do hábito onde Suárez busca reduzir ontologicamente a denominação extrinseca tanto à forma denominante quanto à coisa denominada e a passagem da Disputação 54 onde Suárez diferencia a denominação extrínseca dos entia rationis.

Um homem que dorme de pijama está vestido, ainda que ninguém o esteja observando ao dormir. A roupa não sofre nenhuma alteração por vestir alguém, senão uma alteração acidental que diz respeito ao lugar (ubi), isto é, somente o modus intrinsecus do acidente do onde altera-se com o vestir. Mas esta alteração do modus do lugar enquanto alteração de um modus não é uma denominação extrinseca. A denominação extrínseca surge, porém, logo após esta alteração do lugar (statim consequitur illa denominatio), e surge, é claro, sem acrescentar qualquer alteração à roupa, de maneira que a denominação extrínseca do hábito na realidade (in re) difere do modo (modus) e da ordenação da roupa no lugar." Concluindo: $\mathrm{O}$ hábito enquanto é uma denominação extrínseca ontologicamente não difere realmente da forma denominante. Contudo, diz Suárez, quando Deus aniquila o homem (vestido) a denominação extrínseca desaparece," o que implicaria que a denominação extrínseca do hábito depende também da realidade da coisa denominada. Temos aqui, portanto, uma inconsistência, pois há denominações extrinsecas, a saber, as dos atos mentais, que denominam não só coisas que existem em ato, mas também coisas possiveis ou somente pensadas (entre as quais inclusive coisas impossiveis).

A respeito da denominção extrínseca de um ato mental denotando uma coisa em ato Suárez nos deixa pensar que a realidade desta denominação extrinseca é a mesma da relação predicamental que surge também devido à semelhança entre a coisa denominada e a forma denominante." Sendo assim temos que Suárez esclarece o estatuto ontológico da denominação extrínseca do ato de ver, a saber, de ver algo que existe em ato, indicando que a realidade desta denominação é a

\footnotetext{
Cf. DM 39 sectio 2.

DM $53,1,3$.

- DM 53,1,5.

- DM $54,2,11$ e idem n. 14.
} 
mesma da da relação predicamental ${ }^{\text {to }}$ que sempre surge neste caso. 0 mesmo valeria, segundo ele, para o ato mental do conhecer ou para o do amar quando eles se referem a coisas existentes em ato. Esta explicação não me parece de todo satisfatória, pois Suárez também fala em denominações extrínsecas devidas a denotaçōes oriundas de atos mentais apenas possiveis tal como é o caso da numerabilidade (ver itens (8) e (9) acima) e não fica claro qual seja o estatuto ontológico destas denominações. Mas que aceitemos que esta explicação é satisfatória, resta ainda o problema mais embaraçoso: o do estatuto ontológico das denominações extrínsecas de atos mentais que se referem a entia rationis.

Suárez, como já sabemos, nega que as denominações extrinsecas sejam entia rationis. Além disso, ele diz que, embora haja denominações extrínsecas que se referem a entia rationis, isto nåo quer dizer que para que um ens rationis surja basta uma denominação extrínseca." Para esclarecer qual seja o estatuto ontológico das denominaçōes extrínsecas referentes a entia rationis Suárez proporá uma posição contrária a sua sem, no entanto, dar o nome de quem poderia ser considerado este seu oponente. Segundo este oponente as denominações extrinsecas oriundas de atos mentais seriam, ou entia rationis, uma vez que elas são apenas objetivamente no intelecto, ou seriam alguma coisa a mais que meros entia rationis, pois elas por vezes não são apenas objetivamente no intelecto, a saber, quando denotam coisas em ato, elas têm - segundo Suárez - a relidade do denotado, além do que elas nem sempre dependem da atividade do intelecto como é o caso das denominationes extrinsecae aptitudinales. Este oponente Suárez contesta, primeiramente, dizendo que o que ele afirma implica que teria de haver um gênero de entes que não seriam nem entia realia nem entia rationis. O modo como Suárez põe este argumento mostra que ele tem como bem aceita a tese que recusa um estatuto ontológico intermediário. Contudo, Suárez busca ainda tornar seu argumento mais robusto. Com esta finalidade ele indica (i) que junto a uma coisa real o ser-denominado não causa nenhuma entidade que possa ser separada dela, ${ }^{\text {,2 }}$ (ii) que o mero referir de um ato mental a uma coisa, uma vez que tal referir nâo é um ato reflexivo, não pode causar nenhum entia rationis" e (iii) que o ens rationis não se caracteriza por ele depender do intelecto, mas porque ele se diferencia do ens reale. Ou seja, Suárez está aqui negando tanto que as denominações extrínsecas sejam algo intermediário entre os entia realia e os entia rationis quanto que elas

* Sobre o predicamento da relação em Suárez cf. Rios $\$ 10$.

4. DM 54,2,11: Dices, hoc esse peculiare in denominatione sumpta ab actibus intellectus, quod possit cadere etiam in entia rationis, et ideo speciali ratione posse appellari ens rationis; sed hoc satis est, nam inde infertur aliquam denominationem extrinsecam posse extendi ad entia rationis, etiamsi alioqui a forma reali sumatur, non vero e converso hanc denominationem sufficere ad constituendum ens rationis.

52 DM 54,2,12: Declaratur hoc, hoc si ens illud, quod constituitur per denominationem extrinsecam $a b$ actu rationis, habet propriam quandam rationem entis condistinctam ab ente reali, ergo etiam ens visum, aut ens amatum, ut sic, et in universum extrinsece denominatum, habebit quandam rationem entis condistinctam ab ente reali; nam est eadem ratio et proportio, ut ostensum est.

Idem: $\mathrm{Si}$ autem fiat vis in nomine entis rationis, quod significare videtur peculiarem dependentiam ab actu rationis, facili negotio multiplicare possumus similia seu proportinalia nomina, ut ens imaginationis, aut sensus, aut voluntatis, etc., quae omnia erunt condistincta ab ente reali propter dictam similitudinem rationis. 
sejam entia rationis. Resta só que elas sejam entia realia, contudo ele não o afirma claramente. $\mathrm{E}$ isto é digno de ser destacado, a saber, que ele não explicita a conclusão que se impõe - ele posterga concluir.

Suárez contesta ainda este oponente argumentando que uma denominação extrínseca de um ato mental não tem ser objetivo (esse objectivum) no intelecto, mas que antes é formalmente no intelecto, a saber, que ela é um conceito formal. Suárez difere, então, entre dois significados do esse cognitum, ou seja, que o esse cognitum é, ou a própria coisa conhecida, ou o conteúdo inerindo no intelecto enquanto conceito formal no que ele é conhecido reflexivamente." $O$ que podemos concluir deste segundo argumento é que Suárez, mais uma vez, recusa que possa haver uma realidade intermediária entre o ser no intelecto e o ser das coisas reais. Contudo, Suárez continua sem pronunciar-se com clareza sobre o estatuto ontológico das denominaçōes extrínsecas. Nesta passagem Suárez não se pronuncia com clareza senão sobre as denominções extrinsecas oriundas de formas reais. Neste caso Suárez as alinha aos entia realia, embora ele - ao que me parece - veja-se como que forçado a amenizar o modo de expressar-se. Ao invés de dizer diretamente "comprehendi sub entibus realibus", ele diz "sub latitudine entis realis" e ainda acrescenta uma ponderada restrição: "ao menos pelo lado da forma denominante". Assim penso poder constatar novamente uma certa reserva, visto que afinal Suárez está exatamente se esquivando do problema de fato incômodo, isto é, o do estatuto ontológico da denominação extrínseca que denota os entia rationis, para mais uma vez falar das denominações que denotam os entia realia.

Esta mesma reserva pode-se também ser observada numa breve passagem do De anima quando está em questão qual seja o estatuto ontológico da secunda intentio formalis. A secunda intentio formalis que, para Suárez, consiste numa denominação extrinseca de um conceito formal não é, nem algo que, sem dúvida, existe em ato como é o caso do universale physicum, nem é um ens rationis como o universale logicum. Suárez entende que a secunda intentio formalis é o universale metaphysicum e contesta, o que não nos surpreende, que este universal não seja nem um ens reale nem um ens rationis. Então ele conclui:

Universale denique secundo modo [sc. o universale metaphysicum] reale aliquid est, rem tamen extrinsece denominans (Grifado por mim).

B, por fim, o universal no segundo modo [sc. o universale metaphysicum] é algo de real, que, com efeito, denomina extrinsecamente a coisa.

Suárez parece estar aqui medindo bem as palavras. Ele não diz simplesmente que o universal metafísico é real, mas antes que ele é, como que relativizando, algo ("aliquid") de real. Sendo que ainda o "tamen" confere à segunda frase uma nuance adversativa, nuance que sugere que algo que, afinal deveria ser simplesmente real, na verdade, porém, acaba por ser algo que de certo modo contrariaria esta realidade e mesmo que só seria "algo real" enquanto é, porém, menos real, isto é, enquanto é uma denominação extrínseca de algo de fato real. Em DM 6,7,2

" DM 54,2,13; retornarei a esta passagem mais abaixo no $§ 3$.

s. DM 54,2,14. 
diz igualmente Suárez que os universais apenas "permissive" podem ser compreendidos como entia realia."

O motivo deste modo de expressar-se reservado é, sem dúvida, sempre o mesmo. A metafísica de Suárez, para poder desdobrar-se sistematicamente, requer algo de intermediário (ou antes algo ambivalente, isto é, requer um double bind), de modo que Suárez não pode simplesmente alinhar as denominações extrínsecas aos entes reais. Se ele o fizesse teria de recorrer a algum outro intermediário. Entretanto, Suárez não aceita que se postule a autonomia e a especificidade ontológica de entes intermediários com funções semânticas. Uma argumentação formal contra estas entidades não é apresentada por Suárez, embora ele certamente conheça a teoria dos complexa significabilia de Rimini. O fato é que ele recusa tais entidades e que ele teria muitos argumentos quer na tradição escolástica quer apenas no tomismo para justificar tal recusa. Além disso Suárez recusa que as denominações extrinsecas sejam entia rationis, pois para Suárez os entia rationis surgem só a partir de atos mentais reflexivos e as denominações extrínsecas não são reflexivas. Não são reflexivas embora sejam, por assim dizer, sólidas o suficiente para suportarem sob si a visada de um segundo ato mental, a saber, de um ato mental reflexivo do qual então podem surgir entia rationis. Ou seja, as denominações extrínsecas não podem causar um ens rationis, mas são já algo positivo 0 suficiente para que sobre elas se apoie a produção de entia rationis. Portanto elas diferem claramente dos entia rationis, embora ainda siga sempre dificil reduzi-las ontologicamente aos entes reais, uma vez que há denominações extrínsecas oriundas de formas denominantes inexistentes e denominações extrinsecas de coisas denominadas inexistentes. A reserva ou a hesitação de Suárez não é só um embaraço frente a questões ontológicas, mas é também o que lhe possibilita agilizar sua metafísica, pois é porque ele permanece inconcluso frente ao estatuto ontológico da denominação extrínseca que a denominação extrinseca segue, devido mesmo a esta indefinição, funcionando em sua metafísica, a saber, segue assumindo funções semânticas.

Assim a denominação extrínseca deixa atrás de si um rastro de argumentações dúbias. Dubiedade que se deve à duplicidade da denominação extrinseca ela mesma, isto é, à posição de double bind que a denominação extrínseca tem - por um lado - na metafísica de Suárez, quando ela tanto é algo real quanto não é real, e - por outro lado - na semântica de Suárez, quando ela tanto é da ordem de uma dimensão semântica autônoma quanto uma tal dimensão semântica é negada $\mathrm{e}$ reduzida ao real (isto é, ora é reduzida à realidade das coisas exteriores ora à dos atos mentais). Tal duplicidade debilita as argumentaçōes acima expostas: elas podem, assim, ser facilmente questionadas. De fato, tais argumentaçōes poderiam também, sem dificuldade, estar a serviço de demonstrar o contrário do que elas visam concluir.

0 argumento de que a aniquilação do homem não altera a vestimenta e que 0 despir o homem não altera o homem não implica propriamente que a denominação extrínseca do estar-vestido consista na realidade destes correlatos, pois este ar-

* DM 6,7,2: Et ideo dicimus, permissive seu indefinite universalia esse entia realia, non tamen necessario et ominio universaliter. 
gumento pode, ao contrário, implicar que ela exatamente não consiste na realidade deles. Ficania provado que a denominação extrínseca do hábito não consiste na realidade dos correlatos, pois, se ela consistisse na realidade deles, como Suárez supôs, então, aniquilado um correlato, a outra parte da realidade do hábito também seria aniquilada no outro correlato o que alteraria este outro correlato; mas, se a aniquilação de um correlato, não altera o outro correlato, o que se pode então concluir é que nem um nem outro correlato do hábito possuem a realidade do hábito, ou seja, que o acidente do hábito, isto é, a denominação extrínseca que o constitui, é algo ontologicamente independente dos correlatos.

0 argumento que uma denominaçāo extrínseca não pode causar um ens rationis e que ela difere dos entia rationis não leva necessariamente à conclusão de que, no caso das denominaçōes de coisas reais por atos mentais, a denominação extrinseca seja algo real, a saber, o conceito objetivo junto as coisas reais; pois, se - dada uma coisa não denominada - a denominação não acrescenta nada a esta coisa, então a denominação é ontologicamente nula.

Reparar que a duplicidade da denominação extrinseca expressa-se já na impossibilidade de Suárez localizá-la na sistematicidade das DM. À denominação extrínseca não cabe uma disputação própria. Nem ela é tratada sistematicamente no interior de uma disputaçâo. É mesmo dúbio se ela é algo a ser discutido na metafisica (ainda que a definição do conceito de ente dependa dela!), pois afinal Suárez nunca chega a afirmá-la, sem reservas, que ela seja real. Deveria ela ser tratada numa semântica? Uma semântica enquanto tal, isto é, autônoma frente à metafísica não é aceita por Suárez. E deveria ela ser tratada numa psicologia, isto é, no De anima? A temática do 'De anima é porém para Suárez assunto para quem pesquisa a fisica; ${ }^{\rrbracket}$ portanto não se pode esperar que algo que participa da fundamentaçăo da metafísica, como é o caso da denominação extrínseca, venha a ser explicada pela física. Ou seja, a denominação extrínseca não tem um lugar próprio na metafisica mas está nela por toda a parte, inclusive em seu fundamento. Não está também propriamente nem na metafísica nem numa semântica nem na fisica, mas participa de todas elas. Por fim, pode-se dizer ainda que a denominação extrínseca está tanto acima da metafisica - pois é um pressuposto nunca realmente esclarecido por ela - quanto abaixo dela - pois de certa forma a denominação extrinseca é remetida à física que, enquanto pesquisa da alma e dos atos mentais psicológicos, é uma ciência inferior à metafisica.

\section{§3 - A denominação extrínseca e os entia rationis}

Uma vez que o objeto adequado para o intelecto humano é o ser, forçosamente o homem sempre compreende tudo direcionando-se pelo ser (ad modum entis)." $\mathrm{O}$ intelecto compreende assim, tanto o que é como algo que é, quanto o que não é como se fosse. Este é o caso quando dizemos que alguém é cego, pois

57. Cf. DM 8, prooemium: ...secunda [sc. o segundo tipo de verdade, isto é, a verdade in cognoscendo que é propriamente a verdade das proposiçōes] ad physicum, quatenus de anima ejusque functionibus considerat.

* DM 54,1,8: Cum enim objectum adaequatum intellectus sit ens, nihil potest concipere, nisi ad modum entis, et ideo dum privationes aut negationes concipere conatur, eas concipit ad modum entium, et ita format entia rationis. 
propriamente ninguém "é" cego, a rigor a cegueira não é nada. À cegueira não corresponde nenhuma entidade real; ela é apenas a carência da capacidade de ver." $\mathrm{O}$ que se passa é que nosso intelecto é tăo fecundo (ex quadam foecunditate intellectus) que nós por meio dos entes reais podemos constituir ficções, a saber, compondo partes das coisas reais; é assim que chegamos a constituir entia impossibilia como, p. ex., a quimera. ${ }^{\infty}$

Suárez define o ens rationis como aquilo que só é objetivamente no intelecto, isto é, o ens rationis é algo que só o intelecto - no que ele pensa - considera e que em si não possui nenhuma entidade." Importante nesta definição é a expressão "só objetivamente no intelecto" (tantum in intellectu), pois tanto o ens rationis quanto 0 ens reale podem ser objetivamente no intelecto." A diferença entre ens rationis e ens reale consiste em que o ens reale não se dá "só" objetivamente no intelecto, mas também é por si mesmo. " Para um ente real é extrinseco se ele também é objetivamente num intelecto ou não:" para um ens rationis, ao contrário, é essencial que ele esteja sendo objetivamente num intelecto.

Mas se o ens rationis não é um ente real então ele não é nada. Não obstante, ele tem uma causa eficiente. $\mathrm{O}$ ens rationis é causado pelo intelecto." Suárez argumenta que um ente de razão tem de ter uma causa eficiente uma vez que ele passa a ter um esse objectivum que ele não tinha. ${ }^{\infty}$ Ou seja, Suárez afirma que o ente de razão tem uma causa eficiente porque ele quer contestar que algo possa ser sem ter uma causa, pois se algo assim fosse então este algo seria eterno. Além disso, Suárez sustenta também que o ente de razão é algo, pois, de alguma maneira (aliquo modo) um conceito formal pode apreendê-lo ou alcançá-lo

* ...ut cum dicimus hominem esse caecum, nam illud esse non indicat aliquid quod sit in homine, sed potius adjuncto tali praedicato ab illo aliquid removet; tamen quia intellectus per modum entis aprehendit illam carentiam visus, ideo illam esse dicit in homine, quod esse significat veritatem propositionis, non existentiam in re.

DM 54,1,8: Est tamen. causa proveniens ex quadam foecunditate intellectus, qui potest ex veris entibus ficta conficere, conjungendo partes quae in re componi non possunt, quomodo fingit chymaeram, aut quid simile, et ita format illa entia rationis, quae vocantur impossibilia, et ab aliquibus dicuntur entia prohibita.

m DM 54,1,6: Et ideo recte definiri solet, ens rationis, esse fllud, quod habet esse objective tantum in intellectu, seu esse id, quod a ratione cogitatur ut ens, cum tamen in se entitatem non habeat.

- DM 54,1,6: Et ideo recte definiri solet, ens rationis, esse illud, quod habet esse objective tantum in intellectu, seu esse id, quod a ratione cogitatur ut ens, cum tamen in se entitatem non habeat. DM 54,1,5: ...non solum inhaesive per suam imaginem, sed etiam objective secundum seipsam.

i DM 54,1,6: Id autem, quod sic est objective in mente, interdum habet, vel potest habere in se verum esse reale, secundum quod rationi objicitur, et hoc absolute et simpliciter non est verum ens rationis, sed reale, quia hoc esse est quod simpliciter ac per se illi convenit, objici autem rationi est illi extrinsecum et accidentale.

- DM 54,2,3: ...necessario est... dari aliquam causam efficientem, a qua habet ens rationis ut suo modo sit, quanquam efficientia ejus, ut est realis productio, ad illud non terminetur, ut ad terminum effectionis, sed tantum ut ad objectum ipsius termini producti.

DM 54,2,3: Probatur, quia quanvis ens rationis non habeat esse reale, habet tamen esse objectivum, quod tamen non semper habet; ergo quod nunc illud habeat, et non antea, in aliquam causam aliquo modo efficientem referendum est; alioqui nulla ratio sufficiens illius qualiscunque vartetatis reddi posset. Item illud esse objectivum, quamvis in ipso ente rationis nihil sit, tamen necessario supponit aliquod esse reale, in quo fundetur, vel a cujus denominatione seu habitudine illud esse objectivum quasi resultet; illa ergo causa, quae efficit tale esse reale, est causa entis rationis. 
(terminetur)." É certamente bem difícil de esclarecer no que consiste exatamente esta terminação ou termo do conceito formal. Revius não perdeu também aqui a oportunidade de criticar Suárez." A dificuldade, em minha opiniäo, consiste aqui em que Suárez procede como se ele acreditasse ser possivel reduzir ontologicamente o ens rationis ao ato mental sem deixar nenhum resto. Ele nảo se dá conta - ou evita se dar conta - de que um ente de razão não pode em sua totalidade ser causado pelo intelecto. 0 que estou indicando é que 0 ente de razão pressupõe também algo que excede a causalidade estritamente ontológica. Se toda a causalidade dos entes de razão se reduzisse à causalidade ontológica do ato mental, então nós não poderiamos compreender a Odisséia nem poderiamos contar fábulas para as crianças. Se nós ouvimos a palavra "sereia" nós a comprendemos porque nós causamos um ente de razão. A palavra "sereia" tem porém um sentido unitário, a saber, o sentido pelo qual o nosso intelecto (e conseqüentemente nossa imaginação) se orienta ao pôr-se em atividade."

A doutrina de Suárez sobre os entes de razão pressupōe portanto que nós disponhamos de significados unitários. Tais significados não podem ser causados por uma causalidade ontológica efetiva. Porém Suárez não explicita a pressuposiÇão de que haveria estes significados, antes - como se vê na Disputação 2 - ele também procede como se o significado, isto é, o conceito formal enquanto significatio/imago, pudesse também ser reduzida sem resto ao ato mental. ${ }^{\text {}}$

Em outras palavras, podemos dizer que o ens rationis é algo que surge com um conceito formal que não se direciona diretamente para uma coisa mas para um outro conceito formal, sendo que ele não se direciona para um conceito formal não enquanto ele é algo físico (isto é, enquanto ele é um ato mental, ou seja, enquanto ele é um movimento na alma), mas enquanto este conceito formal é uma significatio/imago, isto é, enquanto ele é algo comum a muitos. Um ens rationis pode surgir também quando um conceito formal se dirige não a um outro conceito formal, mas o que a ele corresponde junto às coisas. É porque Suárez não leva em conta este elemento, por assim dizer, semântico e comum dos entes de razão, que ele mantém a possibilidade de uma redução sem resto do ente de razão ao ato mental. Assim ele entende que o ente de razão enquanto termo ou terminação do conceito formal é apenas um efeito secundário deste."

- Ib.: ...tota vero illa efficientia, ut ad terminum realis productionis terminatur ad formalem conceptum ipsius mentis, et ibi sistit; inde tamen fit, ut illemet conceptus formalis terminetur aliquo modo, ut ad objectum, ad ipsum ens rationis, quod cogitatur aut fingitur.

* Cf. Revius[1] a passagem correspondente.

* Há que se indicar aqui que é o intelecto que propriamente causa os entia rationis e não a imaginação. A imaginação também causa entia rationis, mas o faz somente porque o intelecto atua conjuntamente causando esta espécie de ens rationis que é o ens imaginabile. DM 54,2,18: Atque ita sane dicendum est, ea entia rationis, quae sunt mere impossibilia, et non habent aliud fundamentum in re, praeter vim potentiae componentis quae in re componi non possunt, etiam posse fingi per imaginationem; tamen, quia imaginatio humana in hoc participat aliquo modo vim rationis, et fortasse nunquam id facit nisi cooperante ratione, ideo haec omnia dicuntur entia rationis, et, simpliciter loquendo, etiam hoc munus rationi tribuitur.

Cf. Rios [1].

n DM 54,2,4: ...intellectus est causa efficiens entium rationis; efficit autem illa, efficiendo solum aliquam cogitationem, vel conceptum suum, ratione cujus dicitur ens rationis habere esse objectivum in intellectu. 
Suárez deixa, portanto, de lado a questão desta, por assim dizer, dimensão semântica, que é subrepticiamente pressuposta na gênese dos entes de razão, mas ele se vê obrigado a expor a diferença entre o ens rationis e a denominatio extrinseca. Como já indiquei o conceito de denominação extrinseca é fundamental no pensamento de Suárez, a saber, de tal modo fundamental que ele nunca chega a explicitá-lo. Minha posição é mesmo a de que ele não pode explicitá-lo, que a duplicidade da denominação extrinseca é necessária para a sistematicidade das DM. Seja como for, Suárez não quer deixar os entia rationis sem rédeas. Antes ele precisa delimitar com clareza os domínios deles, deste não-ser, para que também se possa ter clareza dos limites da metafísica enquanto ciência do ser. É já na Disputação 1 que Suárez indica que dedicará toda uma disputação para os entes de razão. De fato com este zelo ele parece estar dando maior firmeza ao projeto de sua metafisica. Se ele, ainda assim, não consegue dissipar certas dificuldades da doutrina dos entes de razão é exatamente porque ela se escora neste, por assim dizer, sem fundo de sua metafísica que é a denominação extrínseca em sua interação com a face nâo mental do conceito formal.

Suárez rejeita a opinião de que os entia rationis não seriam nada mais do que denominaçōes extrínsecas. ${ }^{n}$ Segundo esta opinião se deveria considerar, junto às coisas, o ser-conhecido como um ens rationis, pois a denominação extrinseca não acrescenta nada à coisa e, conseqüentemente, só existe objetivamente no intelecto. ${ }^{n}$ Desta opinião que Suárez rejeita seguiriam conclusões inaceitáveis:

(1) Também o intelecto divino, no que ele conhecesse coisas constituiria entes de razão."

(2) Não só o intelecto, mas também a vontade, a visão etc. constituiriam pela sua simples atividade entes de razão, pois o ser-desejado ou o ser-visto são, enquanto são denominaçỏes extrinsecas, também dependentes do ato que por sua intencionalidade denota a coisa. ${ }^{*}$

(3) Os entes de razão não só surgiriam de atos das potências vitais (potentiarum vitalium), mas também das denominações que as coisas têm independentemente do intelecto; neste caso o estar-vestido (isto é, o habitus enquanto décimo predicamento que é, para Suárez, uma denominação extrínseca) seria um ens rationis."

n DM 54,2,6: Est ergo quorumdam opinio, entia rationis nihil aliud esse quam denominationem extrinsecam, qua res cognita denominatur ab actu intellectus secundum aliquam proprietatem, aut conditionem convenientem illi quatenus cognita est, quae denominatio potest multiplex.

7 I b.: ...videtur esse illa [sc. opinio], qua dicitur res esse cognita, nam haec etiam est denominatio extrinseca proveniens ab actu rationis, et non cadit in rem, nisi prout est objective in mente.

* DM 54,2,7: Et juxta hanc sententiam sequitur primo, entia rationis non tantum resultare suo modo in rebus cognitis per intellectum humanum vel creatum, sed etiam per intellectum divinum, quia etiam prout illi objiciuntur, denominantur cognitae.

` DM 54,2,8: Secundo sequitur ex praedicta sententia, non solum per intellectum, sed etiam per voluntatem, imo et per visum, et per alios similes actus resultare entia rationis, quia etiam ex illis denominantur objecta secundum aliquod esse, quod in eis nihil est, videlicet, esse volitum, aut esse visum.

* DM 54,2,9: Tertio infertur ex dicta sententia, non solum dari entia rationis ex vi horum actuum potentiarum vitalium, sed etiam ex aliis rebus vel habitudinis rerum posse consurgere, quia in rebus ipsis ante hos actus inveniuntur aliquae extrinsecae denominationes, quae nihil in eis ponunt, et consequenter etiam erunt entia rationis. Hujusmodi est denominatio, qua columna dicitur dextra 
Contra esta opinião indica Suárez ainda que ela pressupõe uma regra totalmente inaceitável, a saber, que uma denominação extrínseca poderia causar um ens rationis." Esta regra geral é inaceitável porque há já junto às coisas, independentemente do intelecto, formas denotantes, isto é, denominações extrinsecas, de modo que haveria entes de razão independentes do intelecto.

Ainda que Suárez nunca chegue a esclarecer o estatuto ontológico das denominações extrínsecas, ele considera importante esclarecer porque e como os entia rationis diferem das denominaçōes extrinsecas. Há sem dúvida uma certa proximidade entre ambos: as denominaçōes extrisecas podem, p. ex., servir de fundamento para que um ato intelectual reflexivo dirigido a ela constitua ficticiamente um ens rationis. Mas a denominaçāo extrínseca nunca é reflexiva enquanto, ao contrário, um ens rationis sempre resulta de um ato mental reflexivo."

Suárez expõe com mais clareza como surge um ens rationis ao discutir o esse cognitum. $O$ esse cognitum pode ser entendido de duas maneiras. Por um lado, o esse cognitum é uma denominação extrínseca (neste caso trata-se, junto à coisa, do ser-denotado, ou seja, do ser-conhecido), por outro lado, o esse cognitum é um conhecimento reflexivo do ser-conhecido da coisa conhecida. No primeiro não se trata, é isto que nos diz Suárez, de um mero ser objetivo no intelecto, mas do próprio ser da coisa que está sendo conhecido pelo intelecto. ${ }^{\circ}$ No segundo caso é que se trata do ser objetivo do ato reflexivo no qual o intelecto conhece o seu próprio ato, a saber, conhece o ser-conhecido de seus conteúdos. ${ }^{*}$

A reflexividade do ato mental da qual surge um ente de razão consiste em que, ou o ato mental se direciona para um outro ato mental enquanto algo denotante (ou seja, se direciona para o seu conteúdo intencional), ou o ato mental se direciona para o que, junto a coisa, corresponde a este ato mental. Um bom exemplo aqui é o das secundae intentiones. As secundae intentiones surgem do ato mental que não se volta diretamente para uma coisa, mas para as denominações

vel sinistra animali; item illa quae redundat in objectum ex potentia ut sic, ut esse visibile, vel audibile; denique omnes illae relationes non mutuae, quae ex parte alterius extremi dicuntur esse rationis, aut denominationes extrinsecae ab aliis extremis. Quin potius, a paritate rationis sequitur, denominationem vestiti a veste, locati a loco, imo et agentis ab actione, esse entia rationis, quia est eadem vel proportionalis ratio.

" DM 54,2,10: Haec igitur corollaria satis, ut opinor, declarant, illam sententiam non posse esse veram quantum ad hanc generalem regulam, quod denominatio extrinseca ut sic constituat ens rationis.

* Não é necessário aqui que eu entre em detalhes sobre a questão da reflexividade in actu signato ou significato e a reflexividade in actu exercito. A reflexividade in actu exercito e a reflexividade própria ao juizo de verdade, é uma reflexividade peculiar que não chega a causar um ens rationis. Sobre esta questão e a questão da verdade em geral em Suárez cf. Rios [1]. DM 54,2,16: ...actus intellectus, quo ens rationis consurgit, est aliquo modo comparativus, vel reflexivus, praesertim quando ens rationis fundatur in actu íntellectus.

n DM 54,2,13: ...illudmet esse quod res habere dicitur, ex eo praecise quod cognoscitur, quod ex vi cognitionis directae non est objective in intellectu, sed potius est formaliter ab actu quo res cognoscitur...

* Ib.: ...objective autem est in cognitione reflexa, qua intellectus cognoscit se cognoscere, vel potius qua cognoscit rem esse cognitam. 
de um ato mental direto." Esta é a reflexividade in actu signato que Suárez, na Disputação 8, discute contrastando com a reflexividade in actu exercito característica do juízo de verdade. Com esta reflexividade in actu signato surge, p. ex., o ens rationis "gênero dos animais". O que Suárez não menciona aqui é que o ens rationis "gênero dos animais" que eu tenho objetivamente em meu intelecto não surgiu só porque um dos meus atos mentais reflexivos se direcionou para a denominação de um meu único conteúdo representacional deste cão ou para uma outra denominação de um único conteúdo representacional deste cavalo singular aqui etc., mas que antes este ens rationis de um gênero surgiu porque 0 ato mental se voltou para o denotar, isto é, para o conteúdo representacional comum ou universal próprio a um conceptus formalis communis de animal; e mais: não pode se tratar aqui do conceito formal que eu hoje ou que eu agora tenho em minha alma, mas de um conceito formal que cada um tem ou pode ter, a saber, há que se tratar do denotar (isto é, do conteúdo denotativo ou representacional) do conceito formal que enquanto imago ou significatio independe da face física e singular do ato mental.

Suárez concebe sua doutrina dos entia rationis certamente com o intuito de resolver alguns problemas semânticos que lhe eram incômodos. P. ex., a questão de a que nós nos referimos quando falamos sobre objetos abstratos como gêneros, espécies, entia impossibilia etc. De fato sua doutrina do ens rationis pode responder bem a estas questões, porém só após ele haver, contrariamente ao seu discurso explícito, deixado que funcionasse uma, por assim dizer, dimensão semântica, no caso, após ele haver pressuposto significações universais basicamente independentes dos atos mentais individuais. Ou seja, ainda que concedêssemos que Suárez com a sua prometida Disputação 54 teria conseguido "domar" os entia rationis banindo-os para além das fronteiras de sua metafísica, teriamos de reconhecer que esta Disputação 54 antes reforça a duplicidade da denominação extrínseca. Duplicidade da qual, aliás, os próprios entes de razão também dependem, uma vez que eles se constituem baseando-se em denominaçöes extrínsecas. ${ }^{n}$

n Ib.: Atque ad hunc modum fiunt omnes similes secundae intentiones per conceptus reflexos supra priores denominationes provenientes ex conceptibus directis, quae, ut diximus, non pertinent ad proproam rationem entis rationis seu ficti, de quo nunc tractamus.

n Cabe ainda assinalar que Suárez obtém com sua doutrina resultados que são coerentes com outros aspectos de seu pensamento. Pode-se, p. ex., reparar que para ele Deus nunca precisa, para conhecer uma coisa, de causar entes de razão, pois, dado que ele conhece tudo de uma só vez, é mesmo a completude de seu conhecimento que exclui que ele, tal como os homens, tenha de recorrer a atos mentais reflexivos e comparativos para compreender algo [DM 54,2,20-22]. Isto também não quer dizer que Deus năo conheça os entes de razăo; ele não precisa constituí-los ficcionalmente para conhecer o mundo, mas ele os conhece na medida em que ele conhece o intelecto humano e, portanto, conhece tudo o que o intelecto humano pode causar. DM 54,2,23: Declarari potest, quia Deus comprehendit omnes actiones humanae imaginationis vel rationis; ergo comprehendit omnes fictiones formales (ut ita dicam) quae in his potentiis esse possunt; ergo etiam cognoscit fictiones objectivas quae illis actibus mentis correspondent seu objiciuntur, atque ita cognoscit omnia entia rationis, quae per operationes harum potentiarum quovis modo insurgere possunt. Uma apresentaçăo completa das outras sectiones da Disputação 54 pode ser encontrada no artigo de Yela Utilla. Uma exposição de todas estas seçōes pouco acrescentaria ao nosso trabalho. 
Sabe-se que Suárez usa a palavra "realis" ora no sentido de "atual" "atual" = "em ato") ora referindo-se à realidade antes de sua efetivação." Assim temos, por um lado, que uma relação "real" não é propriamente uma relação "atual" e que, por outro lado, o conceito de ens reale diz respeito às aptitudines ad esse, às quais a principio não se atribui nenhuma atualidade. Esta ambigüidade se transmite para a palavra "ens". Sendo assim é necessário se perguntar o que Suárez em DM $54,1,8$ está então dizendo quando ele fala que nós compreendemos tudo "ad modum entis". Penso que aqui a palavra "ens" refere-se à não repugnância a ser atualmente e não à própria atualidade. Contudo, nós podemos constituir ficcionalmente entia rationis não só em vista ao ens enquanto mera possibilidade, mas também em vista da própria atualidade. Este é o caso quando nós falamos do ens in potentia, pois este é a rigor uma abstração e, conseqüentemente, é um ens rationis. Se nós, p. ex., falamos da essência de Pedro como se ela fosse algo que carece de atualidade, então não estariamos falando da essência como mera possibilidade, isto é, como não repugnância a ser atualmente, mas estariamos falando de uma hipóstase desta não repugnância, a qual estaria sendo pensada tal como se ela já fosse algo existindo autonomamente a que a atualidade apenas seria acrescentada como uma parte a mais.

Segundo Suárez, quando nós ouvimos a palavra "ens" nós entendemos primeiramente a não repugnância a ser atualmente. Esta compreensão primeira é uma denominação extrinsenca desta não repugnância. Esta denominação certamente não causa esta não repugnância, mas apenas, por assim dizer, a aicança. Em sỉ mesma esta não repugnância não consiste nesta denominação; em si ela é mais do que esta denotação semântica. Quando nós porém nos permitimos pensar que esta não repugnância é algo que, para além desta denotação semântica, que persiste no modo de um ente atual, então nós deixamos de falar do ser enquanto objeto da metafisica e passamos a falar de um ens rationis, a saber, passamos a falar da hipóstase da denominaçăo extrinseca da não repugnância a ser atualmente.

Deste modo, falar de um esse essentiae que seria intrínseco aos possiveis, seria já voltar as costas para a metafisica e passar a ocupar-se com quimeras, a saber, com entidades que não têm nenhuma atualidade, mas que, segundo o que constituimos ficcionalmente, persistiriam tal como os entes atuais. Por outro lado, querer compreender os possiveis como entia rationis porque eles são, de certo modo, só objetivamente no intelecto, seria compreender de uma maneira comple-

\footnotetext{
Suárez tem sem dúvida consciência desta duplicidade, é ele próprio que a indica: ...dicitur talis essentia, antequam fiat, realis, non propria ac vera realitate quam in se actu habeat, sed quia fieri potest realis, recipiendo veram entitatem a sua causa, quae possibilitas (ut statim latius dicam) ex parte illius solum dicit non repugnantiam, ut fiat; ex parte vero extrinsecae causae dicit virtutem ad illam efficiendam (DM 31,2,2). Sảo numerosos os pesquisadores de Suárez que lamentam esta oscilaçåo em sua terminologia (cf. Wells, nota 8). Esta duplicidade de "realis" não é porém nenhum descuído. Ela está relacionada com a própria dificuldade do conceito de ser como nâo repugnância.
} 
tamente errônea o que seja um ens rationis. Para o seu surgimento um ens rationis requer que se hipostasie uma denotação. de algo real (que, aliás, não precisa ser atual). Se nós ouvimos a Odisséia, nós sabemos que nesta narrativa não são todas as palavras que se referem a coisas reais; assim nós nos esforçamos em constituir ficcionalmente os denotata das palavras que escutamos, por vezes chegamos mesmo a imaginar alguns deles. Se nós escutamos "sereia" nós, por meio de "peixe" e "mulher", compomos num ato reflexivo do intelecto o denotatum ficcional, o qual "sereia" então denomina extrinsecamente. A palavra "sereia" pode assim se referir a um denotatum ficcional. Contrariamente a isso, a palavra "ens" denota, a principio, não o não repugnante enquanto hipóstase, pois trata-se de uma denotação nâo reflexiva que não é antecedida por nenhuma outra denotação. A denotação da palavra "ens" é como que a própria espontaneidade do denotar; como um denotar espontâneo ao qual todo outro denotar é posterior. O que é denotado por esta denotação extrínseca primeira é o ser enquanto não repugnância. Ainda que nós tenhamos o costume, ou mesmo, que sejamos quase sempre levados a - para além desta primeira denotação em sua espontaneidade - constituir um ente ficcional como o referente de "ens", tal ens rationis já então deixou de ser o ens inquantum ens.

Por isso temos de lidar com o discurso metafisico sempre com muita cautela. É como se tivéssemos uma certa tendência a nos desencaminharmos com hipóstases. Este objeto, do qual o "em si" se subtrai a cada vez a nossa compreensão, é o objeto da metafisica. O objeto da metafisica é, contudo, o que apreendemos neste ato mental não reflexivo provocado pela palavra "ens", ou seja, o objeto da metafisica é o conceptus objectivus entis; sendo que para este objeto (a saber, o ens) que ele seja o conceptus objectivus entis não esgota o seu "em si". Toda a vez que ousamos falar o que é este objeto para além do seu conceptus, então nos arriscamos a não mais estar falando dele, mas de uma ficção. Este "oscilar" do ens reale entre apreensibilidade e inapreensibilidade é a sua transcendentalidade. $\mathrm{O}$ conceito de ser é para Suárez, tal como para Duns Scot, transcendental."

Pode-se aqui colocar a questão de se Suárez consideraria algo como uma dimensão semântica da ordem do transcendental, isto é, se ele aceitaria considerar a denominação extrínseca como algo da ordem do semântico e a consideraria como sendo da ordem do transcendental. Pode-se argumentar neste sentido, pois afinal cada vez que nós nos referimos a uma denominação extrínseca, nós constituímos um ente ficcional e não a alcançamos propriamente. Além disso, temos que as denominações extrínsecas não são entes de razão, pois se elas o fossem, então não se teria o que se tomar como base para constituir ficcionalmente um ente de razão. As denominaçōes extrínsecas são assim ao mesmo tempo inacessiveis e constituidoras do processo cognoscitivo. Sem dúvida se pode dizer que as denominações extrínsecas são já um esboço de uma transcendentalidade que ainda virá a ser pensada de um modo mais sistemático. Isto porém não é dizer muito porque o conceito de transcendental é de todo modo nebuloso e, para além da transcendentalidade do ser, há pouco que se possa de fato apreender como sendo um encaminhamento da futura discussão kantiana do transcendental e muito -

\footnotetext{
m Cf. Rios[1] §1.
} 
digamos demais - que se pode especular. O que é, contudo, importante de ser indicado aqui é que há que se diferençar bem o que seria a transcendentalidade do ser e a transcendentalidade da denominação extrínseca. Não se deve fazer do transcendental - ainda que esta palavra nunca deixe de ser algo obscura - um saco de gatos.

A transcendentalidade do ser é o que possibilita a atualização das coisas (inclusive dos atos mentais). A transcendentalidade da denominação extrínseca é o que possibilita o conhecimento no sentido intencional e, conseqüentemente, a linguagem."

Não se deveria confundir o "oscilar" do conceptus objectivus entis entre apreensibilidade/inapreensibilidade do ser com o "oscilar" entre intencionalidade e coisa. Como já indiquei ao discutir a Disputação 2 Suárez também parece haver se confundido aqui. Na Disputação 2 ele começa com uma discussão que se poderia mesmo dizer ser uma discussão semântica do conceito formal de ser e acaba por alcançar o próprio ser. Contudo, Suárez parece nāo se confundir quando ele discute os universais. Ai ele tem clareza de que o que o universal "animal" denota junto às coisas não é nenhuma parte destas coisas. Toda a discussão da distinctio rationis indica que a denominação extrínseca (por meio das quais as distinctiones rationis se tornam possiveis) se devem ao pensamento e, propriamente falando, às coisas. As coisas dependem, sem dúvida, de sua possibilidade transcendental, mas não de que elas sejam apreendidas conceitualmente. Se um intelecto diferencia junto a uma coisa entre essência e existência, a coisa não se modifica por isso. Se um intelecto se refere à não repugnância dos possiveis, os possiveis não ganham por isso nada no seu não repugnar.

Sendo assim temos que a denominação extrínseca do conceito formal constitui o conceito objetivo de ser, mas não o próprio ser, isto é, ela não causa a sua nảo repugnância a ser.

O ser é transcendental, nâo porque a denominção extrínseca que o apreende o seja, mas devido à inapreensibilidade da não repugnância a ser atualmente.

Não é porque nós podemos nos referir aos possiveis que eles podem existir. Antes eles podem existir atualmente e então podemos nós nos referir a sua possibilidade. A possibilidade da metafísica e, do mesmo modo, a possibilidade da linguagem é para Suárez, em última instância, diferente da possibilidade das próprias coisas. A possibilidade da linguagem deve-se para Suárez, em última instância, à possibilidade dos atos mentais e à do processo de abstração. Uma vez que para Suárez a intencionalidade (isto é, o conteúdo denotante) do ato mental não difere ontologicamente do seu suporte, ele não reconhece ao ato mental enquanto ele desempenha funções semânticas nenhuma autonomia ontológica. Ao contrário do que faz Suárez, Frege nega a possibilidade de uma redução sem restos do sentido ("Sinn") ou do pensamento ("Gedanke") ao ato mental.

O próprio Bolzano diferencia entre o semântico e a possibilldade da coisa: "Ferner muss man die blosse Denkbarkeit einer Sache nie mit der Möglichkeit, nicht einmal mit der sogenannten inneren Möglichkeit, welcher das sich selbst Widersprechende entgegensetzt wird, verwechseln" (vol. 1 \& 7 p. 57-58). 
É em vista destas dificuldades que sou reticente frente aos interpretes da escolástica que comparam as "Sätze an sich" de Bolzano com o "formaliter ex se" de Duns Scot ou com os possiveis em Suárez." Apesar da pouca clareza como estas dificuldades são tratadas em Scot e Suárez creio haver mostrado que se trata de duas, por assim dizer, transcendentalidades diversas. Não estou dizendo que a "confusão" entre elas duas não tenha ainda que ser cuidadosamente pensada; em todo o caso esta "confusão" não é um "erro" que possa ser solucionado por uma melhor definição das palavras. Antes tal "confusão" - é isto que estive argumentando - indica duplicidades fundamentais, isto é, próprias ao fundamento que as metafísicas destes pensadores estiveram reivindicando. Cabe porém indicar aqui que, enquanto Bolzano (tal como Frege e Meinong) visavam primeiramente problemas semânticos, Scot e Suárez visavam primeiramente um problema metafisico, a saber, o do fundamento da metafísica.

Doyle pesquisou a doutrina da denominação extrínseca em Suárez porque ele supunha poder relacioná-la com o pensamento de Kant. Ele supunha inicialmente que se poderia vir a compreender melhor $\mathrm{o}$ apriori kantiano através de uma análise sistemática desta doutrina Suáreziana." Ele porém não conseguiu propor nenhuma análise comparativa entre Suárez e Kant que fosse de fato produtiva. Talvez seu insucesso não tivesse sido completo se ele não o tivesse abandonado tão cedo. 0 ser enquanto não repugnância, isto é, os possiveis, são para Suárez objetivamente no intelecto, mas näo "somente" objetivamente no intelecto como o são os entia rationis. Para além do ser objetivamente no intelecto os entia rationis não são nada. Trata-se porém de dois "nadas". Os entia rationis são constituidos ficcionalmente como se ele fossem algo que existisse atualmente ou como se algo thes faltasse. No entanto, os possiveis são "anteriores" ao ser atualmente ou ao ser ficcionalmente. $\mathrm{O}$ ser atualmente deve ser considerado uma contração da não repugnância. Também o ens in potentia enquanto ens rationis deve ser compreendido como uma contração da năo repugnância. O nada da não repugância é, contudo, algo real, enquanto o nada dos entia rationis é apenas algo ficcional.

Leiamos com atenção a seguinte passagem de Suárez:

...quia saepe res nullum habet esse in se, quod sit esse existentiae exercitum, praeter esse quod habet intellectui objectum; quomodo Deus habet veram cognitionem eorum quae nunquam futura sunt, sive cognoscuntur ut possibilia tantum, sive ut ea quae futura fuisset, si hoc vel illud accideret; in his autem objectis non potest facile excogitari conformitas rei ut objectae intellectui, ad seipsam ut in se, quia nullum aliud esse habet in se, praeter illud quod objicitur intellectui."

Nesta passagem Suárez está argumentando contra a concepção de Durandus de que a verdade consiste na conformidade entre o conceito objetivo e a coisa em si mesma. Suárez indica que os possiveis e os futura contingentia não são nada

* Cf. Honnefelder [1] p. 433.

" Doyle p. 122: “...extrinsic denomination itself, my first hope was that a close examination of Suárez's text could reveal rules governing its use, rules which, systematically laid out, might in ways adumbrate the Kantian a priori. What I fiund was that Suárez does observe some conventions, if not actual rules, with regard to extrinsec denomination. I have, however, been unable to find that these conventions in any explicit way anticipate Kant".

. DM 8,1,5. 
para além dos seus conceitos objetivos ("nullum aliud esse habet in se"). Embora o ser näo seja somente objetivamente no intelecto de Deus, o ser é em si nada.

Os puros possiveis e os futura contingentia são, por um lado, não só objetivamente no intelecto, mas são para além disso algo que é em si, a saber, algo que é e é independentemente de seu conceito objetivo. Por outro lado, eles não são em si nada; eles não são, assim, nada para além de seus conceitos objetivos.

Suárez se mostra consciente desta "oscilação". Quando ele nesta mesma passagem" diz que a não repugnância (os possíveis) não são nada para além do seu estar sendo conhecido (isto é: para além de seu conceito objetivo) ele está dizendo que a não repugnância (os possíveis) não são o que assim são porque Deus os conhece, mas ao contrário que Deus os conhece porque eles assim são." A não repugnância é o que soergue o ens do nada, mas ela não é nada. Suárez porém não indica esta "oscilação" e não a discute.

O tema ser/nada será, no entanto, repetidamente discutido nos séculos subseqüentes." Hegel refere-se ao ser como o imediato indeterminado ("das unbestimmte Unmittelbare"). Ele diz ainda: "Este ser é o próprio intuir puro e vazio" ("Dieses Sein ist dies reine, leere Anschauen selbst")." Evidentemente este problema é tratado em Hegel de um modo bem diferente do que um escolástico poderia sequer supor fosse possivel. Certamente também que 0 objetivo de pôr de lado "o espectro da coisa em si que a filosofia crítica ainda deixou como resto" ("von der kritischen Philosophie noch übriggelassene Gespenst des Ding-an-sich") é um objetivo estranho Suárez.

A questão do copertencimento do ser e do nada também é tratada por Heidegger em seu texto "Was ist Metaphysik?": "Das Nichts gibt nicht erst den Gegenbegriff zum Seienden her, sondern gehöhrt ursprünglich zum Wesen selbst"."

Não penso que a repetição desta questão possa sem consideraçōes críticas detidas ser considerada uma continuidade. Sem dúvida há, a cada vez, que se discutir cuidadosamente a própria mudança de significado que esta questão ou, talvez melhor dizendo, que esta aparentemente mesma questão traz consigo. Contudo, esta não é a intenção do presente texto. Gostaria porém, ao menos a

* Cf. Suárez vol. 11 Scientia quam Deus habet de futuris contingentibus lib 2 c. 5 n. 13 p. $360 a$ e Rios [1] $\$ 21$.

* DM 31,6,17: Rursus essentiae creaturarum non ideo tales sunt, aut talem habent connexionem praedicatorum essentialium, quia respiciunt tales rationes vel exemplaria divina, sed potius ideo Deus cognoscit unamquamque rem possibilem in tali essentia et natura, quia talis est cognoscibilis et factibilis, et non alias...

s. Cf. Hübener.

Hegel p. 83.

* Hegel p. 41: “Der konsequenter durchgefuhrte transzendentale Idealismus hat die Nichtigkeit von der kritischen Philosophie noch übriggelassenen Gespensts des Ding-an-sich, dieses abstrakten, von allem Inhalt abgeschiedenen Schattens erkannt und den Zweck gehabt, ihn vollends zu zerstören". O idealismo ao qual Hegel está se referindo não é o seu próprio sistema filosófico, antes ele está aqui assumindo como tarefa para o seu pensamento eliminar este resto que seria a coisa em si kantiana.

* Heidegger p. 119: "Sein und Nichts gehöhren zusammen, aber nicht weil sie beide - vom Hegelschen Begriff des Denkens aus gesehen - in ihrer Unbestimmtheit und Unmittelbarkeit übereinkommen, sondern weil das Sein selbst im Wesen endlich ist und sich nur in der Transzendenz des in das Nichts hinausgehaltenden Daseins offenbart". 
respeito de Kant e Hegel, indicar alguns aspectos que me parecem possam ser relevantes numa posterior discussão; o que indico logo a seguir há ainda que ser melhor investigado. Primeiramente gostaria de indicar que tais comparações em história da filosofia só podem ter sentido (se é que elas chegam a ter sentido) se se tratar de uma comparação, por assim dizer, estrutural. Comparaçōes entre aspectos isolados (tal como, em última instância, procedeu Doyle) não conduzem a nenhum resultado relevante. Honnefelder após haver exposto longamente os conceitos fundamentais de Duns Scot, Suárez e Wolff e de haver então destacado as semelhanças estruturais entre eles, sem deixar de destacar também as divergências, veio, pois tal trajeto o embasava o suficiente, a proceder uma comparação estrutural entre Duns Scot (e implicitamente Suárez) e Kant. Honnefelder resume algumas conclusōes de sua pesquisa do seguinte modo:

Uberblickt man den Strukturaufbau der scientia transcendens bei Scotus und Kant im gan-
zen, dann wird deutlich, dass den drei Stufen, in denen Scotus "Seiendes" bestimmt, drei
wohlbestimmte Stufen bei Kant entsprechen: Dem Begriff des "Seienden" als Subjekt der
Metaphysik entspricht der Begriff der objektiven Realität und des transzendentalen Ge-
genstandes, dem "Seienden", wie wir es und jetzt als "erstes Objekt des Verstandes" an-
gezeigt finden, die Idee eines Inbegriffs der Realität, einer "omnitudo realitatis", und schli-
esslich dem Begriff des unendlichen Seienden das als transzendentales Ideal erkannte "ens
realissimum".

Se substituirmos neste texto Scot por Suárez, poderemos ver que o conceptus objectivus entis em Suárez viria a ser posto em paralelo com a realidade objetiva e o objeto transcendental, ou seja, com a coisa em si. Tenho aqui a impressão que pensar que a face ontológica do conceito objetivo corresponde à coisa em si não seria infundado: a coisa em si, por um lado, não é simplesmente nada, ${ }^{*}$ embora, por outro lado, seja nada e que se possa, neste caso, considerá-la um ens rationis. A, por assim dizer, face semântica do conceito objetivo seria próxima à realidade objetiva kantiana. A "transcendentalidade" da face semântica do conceito objetivo (e aqui ter-se-ia que ter em vista também o conceito formal) seria assim o que nós poderiamos colocar em paralelo com a transcendentalidade kantiana. Contudo, há que se notar, que muitas das categorias kantianas pertenceriam, segundo a metafísica de Suárez, às coisas. Além disso, para Suárez, as denominações extrínsecas dos conceitos objetivos surgem, em última instância, dos atos mentais. As categorias kantianas não têm porém, a princípio, nenhuma relação com um intelecto físico, mas com a apercepção transcendental. Assim, aqui, a comparação parece mais uma vez romper-se. Uma comparação com Hegel tropeçaria em problemas semelhantes. Contudo, como eu disse, estive aqui apenas indicando alguns aspectos a serem melhor pesquisados. Näo considero estar trazendo resultados definitivos.

A respeito da passagem de Suárez citada acima gostaria ainda de destacar que o conceito objetivo (que também é por vezes entendido como um correlato proposicional, isto é, como o correlato de uma composição de conceitos formais")

w Honnefelder [3]. Cf. Honnefelder [2] p. 485.

* Cf. Kant, Prolegomena Akad.-Ausg. vol. 4 p. 288-290.

* Cf. Rios [1] §§ 9 e 11. 
correspondente a uma proposição sobre os possiveis ou sobre os futuros contingentes não deve ser considerada como uma "proposition" (no sentido contemporâneo deste termo) ou um "Satz an sich" de Bolzano. Às proposiçōes (no sentido contemporâneo deste termo) atribui-se verdade ou falsidade; ao conceito objetivo não se atribui verdade nem mesmo quando ele corresponde a uma composição de conceitos formais.

Segundo Suárez, só se atribuí verdade ao conceito formal (enquanto uma repraesentatio intentionalis, " isto é, enquanto uma composição de conceitos formais). Atribui-se porém verdade ao conceito formal se ele tem um conotatum, ainda que este conotatum não seja nada para além de seu conceito objetivo." Deste modo temos que concluir que uma proposição, ou seja, que um "Satz an sich" ou o "Gedanke" fregeano não podem ser considerados como correspondendo só ao conceito formal, mas que eles antes corresponderiam ao conceito formal juntamente como o conceito objetivo. Contudo, se nós considerarmos o conceito formal e o conceito objetivo como um bloco único, então falar - como o faz Suárez - da verdade como conotação praticamente não tem mais nenhum sentido; ao menos se se está referindo a coisas que não são em si nada.

Gostaria de concluir este texto indicando mais algumas questões a serem tratadas em outros artigos. Os futura contingentia, a saber, tanto os futura contingentia absoluta quanto os futura contingentia conditionata devem ser compreendidos ontologicamente tal como os possiveis. Eles são, por um lado, algo para além de seus conceitos objetivos e, por outro lado, não são nada. Enquanto isso, os entia rationis são, para Suárez, para além de seus conceitos objetivos, em todos os sentidos, nada mais do que nada. A questão da não repugnância é abordada por Suárez detidamente nas Disputações 2 e 31 . A aprofundada discussão desta questão que se encontra em Honnefelder[2] dispensa-me de retomá-la mais uma vez.

Quem compreender e aceitar o que Suárez pensa quando ele fala em não repugnância, então pode considerar a questão referente ao estatuto ontológico dos mundos possiveis como solucionada. No que diz respeito a Suárez, assim eu o diria, a dificuldade consiste antes em compreender o seu conceito de ser do que em esclarecer o estatuto ontológico dos mundos possiveis. ${ }^{100}$ Os filósofos modernos, que em geral não têm como ponto de partida o conceito Suáreziano de ser, vêemse, ao contrário, confrontados com a questão de em que consiste ontologicamente os mundos possiveis.

Não estou aqui propriamente interessado na discussão moderna sobre os mundos possiveis. Ela envolve problemas bem diversos: ela mesma é já um problema diverso uma vez que ela está relacionada com uma tentativa de reeditar a metafisica depois de toda a crítica moderna da metafísica, critica esta que ao meu ver impossibilita que se reerga assim tão ingenuamente a metafisica, isto é, que se

* Cf. DM 8,1,6: Consistit [sc. a verdade in cognoscendo] ergo in quadam repraesentatione intentionali, qua, scilicet, fit ut intellectus per actum, vel judicium ita percipiat rem, sicut in se est.

- Cf. Rios [1] $\$ \S 9$ e 11. Notar que o próprio Suárez nâo usa a palavra conotatum, emprego-a aqui por ela ser cómoda e adequada.

1x Quanto aos os futura contingentia Suảrez, quanto à ontologia, mantém-se próximo a Duns Scot. Sua divergència com Scot se deve a ele ter um conceito de liberdade diverso. Cf. Rios[1]. 
queira reerguer a metafísica sem se ocupar em nenhum momento com a discussão fenomenológica do tempo. O que me interessa é destacar a "oscilação"w do conceito de não repugnância, do conceito objetivo e do conceito formal. O que resta é (1) pensar melhor estas "oscilações" - uma vez que elas, não são imperfeiçōes contornáveis, mas que antes acompanham toda a fundamentação da metafísica Suáreziana e o desenvolvimento de seus conceitos mais fundamentais - e (2) discutir qual são propriamente suas funções e sua necessidade, (3) bem como pensar como se dão as sucessivas reapropriações destas "oscilações" tal como se pode constatar na idea de Descartes com sua realitas objectiva e na "objektive Realität" ou "objektive Gültigkeit" em Kant.

\section{Bibliografia citada}

\section{a) Fontes}

Francisco Suárez: Opera omnia, ed. C. Berton, Paris

Jacobus Revius: Syllabus disputationum metaphysicarum cum notis, Lugduni Batavorum 1654

\section{b) Literatura Secundária}

Alcorta, R. M.: La téoria de los modos en Suárez, Madrid 1949

Bolzano, B.: Wissenschaftslehre, ed. J. Berg, Stuttgart - Bad Cannstatt 1985

Doyle, J. P.: Prolegomena to a Study of Extrinsec Denomination in the Work of Francis Suárez, S. J., in: Vivanium 22, 2 (1984) p. $121-160$

Hegel, G. W. F.: Wissenschaft der Logik. Frankfurt a. M. 1981 (Werke in zwanzig Bände vol. 5)

Heidegger, M.: Was ist Metaphysik? in: Heidegger, Wegmarken. Frankfurt 1978 p. 103-121

Hickman, L: Modern Theories of Higher Level Predicates München 1980

Honnefelder, L.: [1] Ens inquantum ens. Der Begriff des Seienden als solchen als Gegenstand der Metaphysik nach der Lehre des Johannes Duns Scotus. (Beiträge zur Geschichte der Philosophie und Theologie des Mittelalters, N. F., vol. 16), 2. A. Münster 1989

- : [2] Scientia transcendens. Die formale Bestimmung der Seiendheit und Realităt in der Metaphysik des Mittelalters und der Neuzeit (Duns Scotus - Suárez - Wolff - Kant - Pierce), Hamburg 1990

und Kant, in: Ioannis Duns Scotus in historia. Acta Sexti Congressus Scotistici Internationalis, Rom (no prelo)

Hübener, W.: Scientia de Aliquo et de Nihilo. Die historischen Voraussetzungen von Leibniz' Ontologiebegriff, in: Hübener, Zum Geist der Prämodeme, Würzburg 1985, p. 84-100

Kant, I.: Kant's gesammelte Schriften. Begonnen von der Königlich Preussischen Akademie der Wissenschaften, Berlin 1900

Rios, A. R.: [1] Die Wahrheit der Aussagesätze und das göttliche Wissen von zukünftig Kontingentem bei Francisco Suárez. Berlin 1991 (Tese de Doutorado)

- : [2] Racionalidade substancial e racionalidade acidental, in: Lógica e Linguagem na Idade Média EDPUCRS (no prelo)

Wells, N. J.: Suárez on the Bternal Truths, I/I, in: The Modern Schoolman 58 (1980/81), pp. 73-104, pp. 159-174

Yela Utrilla, J. F.: El ente de razón en Suárez, in: Pensamiento 4 (1948) p. 271-303

10 Ao longo deste texto usei várias outras palavras além de "oscilação". Estas palavras foram: "duplicidade", "vacilaçảo", "reserva", "intermediário", "double bind", "hesitação", "indefinição"e "transcendentalidade". 


\section{Tradução de DM 2,1,1}

Comecemos aceitando a distinção usual entre conceito formal e conceito objetivo.

O conceito formal é dito ser o próprio ato ou, o que dá no mesmo, a palavra através da qual o intelecto apreende uma coisa ou uma razão comum [algo de comum a muitas coisas]. O conceito formal é dito conceito [conceptus] porque é como a prole da mente. $\mathrm{E}$ é dito formal, porque é a forma última da mente, porque formalmente representa para a mente a coisa conhecida e, ainda, porque é o termo intrínseco e formal da concepção mental [sobretudo neste último aspecto o conceito formal difere do objetivo].

O conceito objetivo é dito a coisa ou o conceito que de um modo próprio e imediato é conhecido ou representado pelo conceito formal. P. ex., quando concebemos um homem $O$ ato que produzimos na mente para conceber tal homem é chamado conceito formal, enquanto o homem conhecido e representado por este ato é dito conceito objetivo. Trata-se de um conceito, portanto, com base numa denominação extrinseca de um conceito formal, a saber, do conceito formal através do qual o objeto é dito ser apreendido. Sendo assim é correto falar-se em objetivo, pois não se trata de um conceito enquanto uma forma intrínseca concluindo um ato de conhecimento, mas enquanto é objeto, ou seja, a matéria acerca da qual versa formaimente o ato de conhecimento, isto é, o conceito objetivo é o conteúdo para $\circ$ qual $\circ$ olhar da mente [a atenção da mente] está diretamente voltado. Por isso o conceito objetivo é chamado por alguns, entre os quais Averróis, intentio intellecta e por outros ratio objectiva.

Visto isso podemos enumerar as diferenças entre o conceito formal e o conceito objetivo.

O conceito formal é sempre verdadeira e positivamente uma coisa e no homem é uma qualidade inerindo na mente.

O conceito objetivo, porém, nem sempre é verdadeira e positivamente uma coisa. De fato por vezes concebemos privaçōes ou coisas semelhantes as quais chamamos de entia rationis lentes conceituais], pois estes só têm objetividade [esse objective] no intelecto.

Assim, o conceito formal é sempre uma coisa singular e individual, pois é uma coisa produzida pelo intelecto e que nele inere.

Já o conceito objetivo pode ser por vezes singular e individual, na medida em que ele pode se contrapor à mente [menti objici] e ser apreendido por um ato formal, mas algumas vezes o conceito objetivo é uma coisa universal, confusa e comum. Tal é o caso do conceito objetivo de homem, de , substância etc.

Nesta disputaçăo tencionamos precipuamente explicar o conceito objetivo do ser enquanto tal em toda a sua abstração, isto é, tal como quando dizemos que ele é o objeto da metafisica. Mas, por ser isto muito dificil e depender em muito de nossa capacidade de compreensão, iniciaremos com a discussão do conceito formal, pois este - assim nos parece - pode ser melhor apreendido. 